\title{
Actual Innocence as a Gateway Through the Statute-of-Limitations Bar on the Filing of Federal Habeas Corpus Petitions
}

\author{
Limin Zheng $\dagger$
}

\section{TABLE of Contents}

Introduction.

I. The Great Writ of Liberty: Development of Federal Habeas Corpus Jurisprudence .

A. Statutory Development of the Writ.......................................... 2109

1. Origin of the Writ......................................................... 2109

2. Modern Federal Habeas Corpus Statutes:

The Pre-I996 Amendments

3. The Antiterrorism and Effective Death Penalty Act of 1996

B. Judicial Development of the Writ: The Supreme Court's

Habeas Corpus Jurisprudence

II. The Actual-Innocence Doctrine

A. The Relevance of Innocence

B. Procedural Barriers to Federal Habeas Corpus Review.

1. The Exhaustion Doctrine and the Procedural-Default Rule

2. Rules Disfavoring Successive or Second Petitions

3. The Cause-and-Prejudice Standard

C. Actual Innocence as a Gateway Through the Procedural Barriers

Copyright $\odot 2002$ California Law Review, Inc. California Law Review, Inc. (CLR) is a California nonprofit corporation. CLR and the authors are solely responsible for the content of their publications.

$\dagger \quad$ J.D. Candidate, School of Law, University of California, Berkeley (Boalt Hall), 2003; Ph.D., University of Pittsburgh, 1997. 1 would like to thank Professor Charles D. Weisselberg, who leads the Death Penalty Clinic at Boalt, for introducing me to the story of Anthony Burton and for his guidance and inspiration throughout this project. Thanks also to Jason Bezis, Mara Krongard, Heather Rosmarin, and Xuqiong Wu, editors of the California Law Review ("CLR"), for their invaluable editorial input. My appreciation extends to other members of the CLR for their hard work, especially Jolina C. Cuaresma, John Janhunen, David Barton, Erik Stallman, Abigail Reyes, and Winslow Taub. 
D. The Standard of Proof for Actual-Innocence Claims

1. Sawyer v. Whitley: The Clear-and-Convincing-Evidence Standard of Proof for "Innocent of the Punishment" Claims

2. Schlup v. Delo: The Probability Standard of Proof for Actual-Innocence Claims.

3. The AEDPA's Clear-and-Convincing-Evidence Standard of Proof for Actual-Innocence Claims in Second and Successive Petitions 2126

III. Critique of the AEDPA's Statute of Limitations.............................. 2127

A. Access to the Writ Unduly Restricted.................................... 2128

B. Purpose of the AEDPA Not Served ............................................ 2131

IV. Actual Innocence as a Gateway Through the AEDPA's Statute of Limitations

A. The Legal Basis and the Necessity for an Actual-Innocence Exception

B. Balancing Equitable Principles 2136

C. The Case for Applying the Schlup v. Delo Probability Standard 


\section{Actual Innocence as a Gateway Through the Statute-of-Limitations Bar on the Filing of Federal Habeas Corpus Petitions}

\section{Limin Zheng}

Since the founding period, a prisoner's right to petition for inquiry into the legality of his incarceration has been an essential check on the abusive exercise of state power. The Antiterrorism and Effective Death Penalty Act of 1996 (the "AEDPA") imposed, for the first time in the nation's history, a statute-of-limitations bar to the filing of federal habeas corpus petitions. As a result, an innocent prisoner who was convicted through an unconstitutional process and who has never before filed a federal habeas corpus petition can be barred from seeking federal habeas corpus review solely because a one-year statute of limitations has expired. This Comment argues that the statute of limitations unduly restricts access to federal habeas corpus review while failing to serve the AEDPA's stated purpose of curtailing frivolous and abusive petitions. This Comment proposes that courts recognize and apply the doctrine of actual innocence as an equitable exception to the AEDPA's statute of limitations. The Comment explains why both policy concerns and precedent support construing the AEDPA's statute-of-limitations provision to allow a state prisoner to bring his time-barred constitutional claims for federal habeas corpus review upon a showing of actual innocence. Further, the Comment argues that courts, in evaluating the validity of an actual-innocence claim, should apply the probability standard articulated by the U.S. Supreme Court in Schlup v. Delo.

\section{INTRODUCTION}

In 1981 three people assaulted Fred Wright at the end of an alley in Pomona, California. Two of the assailants fired shots, and Wright was killed. The police arrested four suspects: Anthony Sneed, Ronald Washington, Derek Washington, and Anthony Burton. ${ }^{1}$ Evidence clearly indicated that Sneed was one of the shooters. Thirteen-year-old Ronald

1. The story of Anthony Burton is based on the Appellant's Petition for Reh'g En Banc, Burton v. Fairman, No. 99-55000, 2001 WL 925513 (9th Cir. Aug. 15, 2001), reh'g en banc denied (9th Cir. Oct. 2, 2001), and cert. denied, 2002 WL 407209 (Mar. 18, 2002) [hereinafter Appellant's Petition]; Appellant's Opening Brief, Burton (No. 99-55000) [hereinafter Appellant's Opening Brief]. 
Washington admitted to being one of the assailants but denied being the second shooter, although trial testimony from prosecution eyewitnesses implicated him as such. The identity of the third assailant was hotly disputed. Derek Washington, Ronald Washington's sixteen-year-old brother, who had argued with the decedent earlier in the evening, denied being the third assailant. Burton also denied being the third assailant. There was evidence exculpating Burton: one defense witness testified that she was speaking to him some distance away from the end of the alley when the gunfire erupted. Nevertheless, the prosecutor charged Burton while offering immunity to the Washington brothers, both of whom testified that Burton was not only the third assailant but also the second shooter. Based solely on the testimonies of the Washington brothers, the jury returned a verdict of first-degree murder against Burton, and he received a life sentence.

Thirteen years after the trial, Ronald Washington recanted. In an August 1995 letter that he wrote to Burton's wife from a prison where he was serving time for an unrelated conviction, he confessed that his trial testimony against Burton was false. ${ }^{2}$ In addition, Washington claimed that the prosecutor, knowing the testimony to be false, had induced him to deliver it. According to Washington, the prosecutor wanted to convict Burton of being the second shooter because he was older than the then thirteenyear-old Washington. Upon receiving the letter, Burton's wife consulted a California judge, who advised the Burtons to retain counsel to investigate the possibility of relief. In late I 995 or early 1996, the Burtons finally found an attorney willing to assist on a pro bono basis. The attorney persuaded an investigator and a handwriting expert to donate their expertise to verify the authenticity of Washington's recantation. In May I996 the investigator interviewed Washington, who wrote and signed a statement attesting that the prosecutor induced him to testify against Burton at trial. In November 1996 the handwriting expert submitted a report confirming the authenticity of Washington's recantation letter. On March 2I, 1997 Burton filed for state postconviction relief in the California Supreme Court.

2. Washington's letter reads:

1 am writing to let you know, 1 know it has been a long time ago, in [andl you know I was scaird [scared] even though Mr. Solomon [the District Attomey] told me he didn't wont [want] me he wanted the both of you. Cause you was older. That why I put you at the seen [scene]. If I can I would like to clean it up now if I can.

I know it has been a long time in [and] I should have been did this eause I do allway [always] think about you, cause I wish thing could have been different. So now I am coming forward. I wish I can change something. I no [know] I can't change the pass [past]. But I can do right by it now.

Cause in the alley I was their [there]. Howl Spring seen me their [there] at the seen [scene]. When all this took place Anthony Burton was up the alley cause he really didn't no [know] his way around. I most definely [definitely] no [know] Anthony Burton didn't do it.

Appellant's Petition, supra note 1, at 4. 
The California Supreme Court denied the petition without comment on January 14, 1998, but Burton's attorney never notified him of the denial. Since Burton was being transferred from one prison to another at the time, he did not learn of the ruling from his wife until March 21, 1998. He immediately contacted his attorney's office for assistance in filing a federal habeas corpus petition but was told that the attorney could not represent him at the federal level. The next day, Burton asked the prison for federal habeas corpus forms and a book on federal habeas corpus practice. However, the prison could not comply with Burton's request because it did not have an operating law library. On May 19, 1998, less than two months after he learned about the California Supreme Court's denial, Burton, with the help of his wife, prepared and filed his first and only federal habeas corpus petition in the U.S. District Court for the Southern District of California.

The district court dismissed the petition as untimely under the Antiterrorism and Effective Death Penalty Act (the "AEDPA" or "Act"), which was enacted on April 24, 1996. ${ }^{3}$ The AEDPA imposed, for the first time in the nation's history, a one-year statute of limitations on the filing of most federal habeas corpus petitions. ${ }^{4}$ The limitation period starts to run from the latest of four enumerated starting dates ${ }^{5}$ and may be tolled while a properly filed application for state postconviction relief is pending. ${ }^{6}$ In Burton's case, the district court held that the "factual predicate" of the claims was discovered when Burton's wife received Washington's recantation letter in August 1995, prior to the enactment of the AEDPA. ${ }^{7}$ Since under Ninth Circuit law the AEDPA's time bar does not apply retroactively in noncapital cases, ${ }^{8}$ the district court deternined that the one-year limitation period for Burton started to run on April 24, 1996, the effective date of the AEDPA, was tolled fron1 March 21, 1997, until January 14, 1998, while Burton's state petition was pending, and was exhausted on February

3. Pub. L. No. 104-132, 110 Stat. 1214 (1996) (Title I, sections 101-108 codified as amended at 28 U.S.C. $\S \S 2241-2255,2261-2266(2000))$.

4. 28 U.S.C. $\$ 2244(d)(1)(2000)$. Section 2244(d)(1) governs state prisoners' petitions. An identical statute-of-limitations provision governing federal prisoners' petitions is codified at section 2255. Both provisions impose a one-year time limit. The time limit is even shorter in certain cases: State death-row inmates must file their applications for writs of habeas corpus within 180 days after conviction if the state elects to provide them with counsel for state postconviction proceedings. See id. $\$ \$ 2261(\mathrm{~b}), 2263(\mathrm{a})$.

5. The statute of limitations starts to run from the latest of "the date on which the judgment became final by the conclusion of direct review," "the date on which the impediment to filing an application created by State action in violation of the Constitution or laws of the United States is removed," "the date on which the constitutional right asserted was initially recognized by the Supreme Court," or "the date on which the factual predicate of the claim or claims presented could have been discovered through the exercise of due diligence." Id. $\S \S 2244$ (d)(1)(A)-(D).

6. Id. $\$ 2244(\mathrm{~d})(2)$.

7. Appellant's Opening Brief, supra note 1, at 10.

8. Calderon v. United States Dist. Ct., 128 F.3d 1283, 1287 (9th Cir. 1997), overruled en banc in part on other grounds by 163 F.3d 530, 539 (9th Cir. 1998). 
$17,1998 .^{9}$ Accordingly, the district court found that Burton's federal habeas corpus petition filed on May 19, 1998 was untimely..$^{10}$

The Ninth Circuit then issued a certificate of appealability. ${ }^{11}$ The certificate expressly raised the issue of whether a showing of actual innocence was sufficient to overcome the AEDPA's time bar. ${ }^{12}$ In a one-page unpublished opinion, the Ninth Circuit affirmed the district court's denial of Burton's habeas corpus petition. ${ }^{13}$ Although the Washington brothers' testimonies at trial provided the sole basis for Burton's conviction, the court found that Ronald Washington's recantation letter confessing false testimony and alleging prosecutorial misconduct was insufficient proof of Burton's probable innocence. ${ }^{14}$ The court thus avoided addressing the question of whether actual innocence would constitute an exception to the oneyear time bar.

The Ninth Circuit's approach is typical of the federal appellate courts. Most circuits have avoided the question of whether actual innocence should be an exception to the AEDPA's statute-of-limitations bar to filing federal habeas corpus petitions. ${ }^{15}$ In Lucidore v. New York State Division of Parole ${ }^{16}$ the Second Circuit "observed without deciding" that the one-year statute of limitations imposed by the AEDPA may violate the Suspension Clause if the petitioner could make a strong showing of actual innocence ${ }^{17}$

9. Appellant's Opening Brief, supra note 1, at 11.

10. Id.

11. Under the AEDPA, for a state prisoner to appeal a district court judge's final order denying federal habeas corpus relief, the denying court or the circuit judge must issue a Certificate of Appealability (also known as "certificate of probable cause"). 28 U.S.C. $\$ 2253$ (c) (2000). In Anthony Burton's case, the district court judge had refused to issue the certificate. See Appellant's Opening Brief, supra note 1 , at 1.

12. Appellant's Opening Brief, supra note 1, at 1.

13. Burton v. Fairman, No. 99-55000, 2001 WL 925513 (9th Cir. Aug. 15, 2001), reh'g en banc denied (9th Cir. Oct. 2, 2001), and cert. denied, 2002 WL 407209 (Mar. 18, 2002).

14. Id. at *1. Two weeks before the Burton decision, the same three-judge panel issued three other memoranda dispositions denying habeas corpus relief in the same fashion to petitions raising the same issue. See Kelly v. Dunean, No. 00-56543, 2001 WL 868352 (9th Cir. Aug. 1, 2001); Kyle v. Duncan, No. 00-55670, 2001 WL 868350 (9th Cir. Aug. 1, 2001); Ruff v. Clarke, No. 00-55329, 2001 WL 868619 (9th Cir. Aug. 1, 2001).

15. At least one district court judge, however, has granted an evidentiary hearing on a state prisoner's time-barred petition on the basis of evidence of actual innocence. See Nickerson v. Roe, No. 98-04909, 2000 WL 33381022 (N.D. Cal. Dec. 11, 2000). In Nickerson, the petitioner filed his federal habeas petition two court-days after the one-year statute of limitations had expired, and his petition was dismissed as untimely. The petitioner moved for reconsideration and submitted with his motion newly discovered exculpatory evidence. In granting the motion for reconsideration, Chief Judge Patel explicitly based her ruling on the evidence of the petitioner's actual innocence. Id. at *1.

16. 209 F.3d 107 (2d Cir. 2000).

17. Id. at 113 (citing Triestman v. United States, 124 F.3d 361, 378-79 (2d Cir. 1997)). The Suspension Clause provides: "The Privilege of the Writ of Habeas Corpus shall not be suspended, unless when in Cases of Rebellion or Invasion the public Safety may require it." U.S. CoNST. art. I, § 9, cl. 2. For more on the debates about whether the Suspension Clause requires federal courts to make available the remedy of habeas corpus, see Charles D. Weisselberg, Evidentiary Hearings in Federal Habeas Corpus Cases, 1990 BYU L. Rev. 131, 134-35 nn.12-13 (1990). For a constitutional challenge 
but concluded that it need not address the constitutionality of the provision because the petitioner did not demonstrate actual innocence. ${ }^{18}$ Other circuits have followed a similar approach. ${ }^{19}$ Only the Tenth Circuit has gone so far as to declare in dicta that the "AEDPA's one-year statute of limitations is subject to equitable tolling ... when a prisoner is actually innocent." $" 20$

The writ of habeas corpus has for centuries served as an indispensable safeguard of an individual's constitutional rights. This Comment argues that, for the writ to continue to do so, courts should construe the AEDPA's statute of limitations to allow an actual-innocence exception. The Comment focuses on the rights of state, rather than federal, prisoners to bring their constitutional claims because the issues raised by state prisoners' federal habeas petitions best illustrate the relevant doctrinal tensions.

Part I describes the development of federal habeas corpus law in the Umited States. First, it details the statutory developinents from the founding period to the adoption of the AEDPA in 1996. Then, it describes the Supreme Court's habeas corpus jurisprudence and the process by which the Court has applied equitable doctrines to shape the writ into its modern forn. By detailing these statutory and judicial developments, Part I explains the legal framework within which modern habeas corpus doctrines operate.

Part II discusses the emergence and operation of the actual-innocence doctrine. Part II.A describes how the actual-innocence doctrine was initially proposed to limit the scope of federal habeas corpus review. Part II.B reviews the procedural barriers that have made it mcreasingly difficult for state prisoners to bring habeas corpus petitions. Part II.C explains how the Supreme Court has applied the actual-innocence doctrine as an equitable exception to certam procedural barriers. Part II.D discusses the standards of

to the AEDPA's statute of limitations, see Peter Sessions, Note, Swift Justice?: Imposing a Statute of Limitations on the Federal Habeas Corpus Petitions of State Prisoners, 70 S. CAL. L. Rev. 1513, 151937 (1997).

18. Lucidore, 209 F.3d at 114.

19. See, e.g., Delaney v. Matesanz, 264 F.3d 7, 8 n.2 (1st Cir. 2001) (stating that the court need not reach the question whether the AEDPA's statute-of-limitations bar would violate the Suspension Clause because the petitioner did not make a showing of actual innocence); Helton v. Sec'y for Dept. of Corrections, 259 F.3d 1310, 1315 (11th Cir. 2001) (acknowledging that "[t]his circuit has yet to decide whether there is an 'actual innocence' exception to AEDPA's one year statute of limitations"). In Wyzykowshi v. Dep't of Corrections, 226 F.3d 1213, 1218 \& n.6 (11th Cir. 2000), the Eleventh Circuit reviewed multiple federal court decisions and determined that those courts had been able to avoid deciding the difficult constitutional issue of whether the Suspension Clause requires an actual innocence exception to the time bar because the petitioners were unable to make a showing of actual innocence. The federal appellate courts' apparent reluctance to address the constitutional issue may in some cases have led them to apply an unduly harsh standard of proof to petitioners' claims of actual innocence.

20. Gibson v. Klinger, 232 F.3d 799, 808 (10th Cir. 2000) (citing Miller v. Marr, 14I F.3d 976, 978 (10th Cir. 1998)). 
proof that are applied in the actual-innocence context. The doctrines described in Part II illustrate how habeas corpus law balances certain interests (comity, federalism, finality, and judicial resources) against others (individual liberty, fundamental fairness, and the integrity of the criminal justice system).

Part III argues that the imposition of a statute of limitations on the filing of federal habeas corpus petitions represents a drastic departure from existing habeas corpus practice and unduly restricts the availability of the writ. It further argues that the one-year time bar does not serve the AEDPA's stated purpose of curtailing frivolous and abusive federal habeas corpus petitions.

Part IV proposes that the actual-innocence doctrine be applied as an equitable exception to the time bar in order to reduce the harsh impact of the AEDPA's statute of limitations. It argues that when the life or liberty of an innocent is at stake, the writ's purpose of safeguarding an individual's constitutional rights and ensuring the integrity of the criminal justice system ought to prevail over any other equitable concerns. Part IV further proposes that courts adopt the probability standard articulated in Schlup $v$. Delo, ${ }^{21}$ rather than the clear-and-convincing-evidence standard that was incorporated into some provisions of the AEDPA, ${ }^{22}$ to evaluate actualinnocence claims in the statute-of-limitations context. Because the writ of habeas corpus stands as the last safeguard protecting personal liberty, a showing of probable innocence must enable a state petitioner to overcome the AEDPA's statute of limitations and bring his constitutional claims before a federal court.

The Great Writ of Liberty: Development of Federal Habeas CORPUS JURISPRUDENCE

A writ of habeas corpus (also known as the "Great Writ") brings the body of a person who is imprisoned or detained before a court for inquiries into the lawfulness of the restraint. ${ }^{23}$ The writ has been hailed as "the great writ of liberty." ${ }^{24}$ In seventeenth-century England, upon receiving a complaint from the prisoner, the king's high court had discretion to issue a writ of habeas corpus if there were probable grounds that the detention was illegal. ${ }^{25}$ The writ would command that the prisoner be brought before it so that inquiries could be made into the cause of his

21. 513 U.S. 298, 327 (1995); see also infra Part II.D.2.

22. See infra notes 63-64 and accompanying text; see also infra Part II.D.3.

23. Habeas corpus, short for habeas corpus ad subjiciendum, literally means "you should have the body for submitting."

24. William F. Duker, a Constitutional History of Habeas Corpus 3 (1980).

25. Id. 
imprisonment. ${ }^{26}$ By enabling an inquiry into the legality of an individual's confinement, the writ safeguarded the integrity of the criminal justice process. ${ }^{27}$ The remedy ensured that "no man ought to be imprisoned but for some certain cause." 28 Despite changes in the scope of the inquiry, this historical purpose remains in place today.

\section{A. Statutory Development of the Writ}

\section{Origin of the Writ}

The cominon-law writ of habeas corpus accompanied the British settlers to America. In the United States, the writ continued to be the "symbol and guardian of individual liberty." 29 The Constitution recognizes and protects its existence: "The Privilege of the Writ of Habeas Corpus shall not be suspended, unless when in Cases of Rebellion or Invasion the public Safety may require it." ${ }^{30}$ Although the Constitution thereby limits the federal government's power to suspend the writ, it does not expressly authorize the federal courts to issue writs of habeas corpus; nor does it define the scope of federal habeas corpus review.

Through legislation, Congress established the power of the federal courts to issue writs. The Judiciary Act of September 24, 1789 gave federal courts the power to grant writs to federal prisoners "for the purpose of an inquiry into the cause of commitment." 31 During the Reconstruction Era, the Habeas Corpus Act of February 5, 1867 expanded federal courts' habeas jurisdiction by extending federal habeas corpus relief to "any person," including state prisoners, detained "in violation of the constitution, or of any treaty or law of the United States." 32

\section{Modern Federal Habeas Corpus Statutes: The Pre-1996 Amendments}

In the Act of June 25, 1948 (the "1948 Act"), Congress codified existing federal habeas corpus statutes and judicial habeas practice at 28 U.S.C. sections 2241 to $2255 .{ }^{33}$ Section 2241 , a general provision concerning the federal courts' power to grant writs, provided that the writ of habeas corpus

26. Id. at 4 .

27. See Ex parte Watkins, 28 U.S. (3 Pet.) 193, 202 (1830) (describing the history of the writ in England).

28. Duker, supra note 24, at 12 (quoting Edward CoKe, The SeCond Part of the INSTItutes OF THE LAWS OF ENGLAND 53 (5th ed. 1671)).

29. Peyton v. Rowe, 391 U.S. 54, 58 (1968).

30. U.S. CONST. art. 1, $\S 9$, cl. 2. For a constitutional history of the writ, see generally DuKER, supra note 24. For a discussion about the history of the Suspension Clause, see Michael Mello \& Donna Duffy, Suspending Justice: The Unconstitutionality of the Proposed Six-Month Time Limit on the Filing of Habeas Corpus Petitions by State Death Row Inmates, 18 N.Y.U. Rev. L. \& Soc. Change 451, 463-65 (1990-1991).

31. Judiciary Act of Sept. 24, 1789, ch. 20, $\$ 14,1$ Stat. 73, 82 (1789).

32. Habeas Corpus Act of Feb. 5, 1867, ch. 28, $\$ 1$, 14 Stat. 385 (1867).

33. Act of June 25, 1948, ch. 646, $§ 1$, Pub. L. No. 80-773, 62 Stat. 869, $964-67$ (1948). 
may extend to any prisoner held in custody "in violation of the Constitution or laws or treaties of the United States."34 Sections 2242 to 2253 set forth the procedures for filing and responding to habeas corpus petitions and appellate review of final decisions. ${ }^{35}$ Sections 2254 and 2255 contained specific provisions concerning state and federal prisoners, respectively. ${ }^{36}$

Although the 1948 Act shaped the statutory federal habeas corpus law into its current form, ${ }^{37}$ Congress actually did little to substantively change the then-existing practice. The revisions "only wrote the specifics of Supreme Court decisions into the statute book." ${ }^{38}$ For example, section 2254's requirement that state prisoners exhaust their state remedies before applying for a writ of habeas corpus was in fact a judicially created rule of comity. ${ }^{39}$ The Supreme Court had imposed this requirement since $1886 .{ }^{40}$

The next major revision of federal habeas corpus statutes took place in 1966, when Congress amended sections 2244 and $2254^{41}$ to introduce "a greater degree of finality of judgments in habeas corpus proceedings." Concerned with the steady increase in the number of applications filed by state prisoners for writs of habeas corpus, Congress sought to alleviate the burden on federal courts by prohibiting repetitive applications by state prisoners and by requiring federal courts to rely on state courts' records of fact-finding in most circumstances. ${ }^{43}$ Revised section 2244 codified the doctrine of res judicata into federal habeas corpus proceedings. ${ }^{44}$ It disfavored claims raised in second or successive petitions ${ }^{45}$ and made denials of federal habeas corpus relief rendered on the merits binding. ${ }^{46}$ Revised section 2254 prescribed procedural rules for evidentiary hearings, which

34. 28 U.S.C $\$ 2241$ (c)(3) (1952).

35. Id. $\S \S 2242-2253$.

36. Id. $§ \S 2254-2255$.

37. Sections 2242,2243 , and 2245-2252 have not been amended since.

38. LARRY W. YaCKLE, Postconviction Remedies 90 (1981).

39. 28 U.S.C. $\$ 2254$ (b) (1952). Comity, the respeet one political entity shows another, is often described as part of federalism-"that federal courts should respect the determinations of state courts regarding the adjudication of constitutional claims." Barry Friedman, Failed Enterprise: The Supreme Court's Habeas Reform, 83 CALIF. L. Rev. 485, 489 (1995).

40. See Ex parte Royall, 117 U.S. 241, 251-53 (1886). See also infra text accompanying notes 107-08.

41. Act of Nov. 2, 1966, Pub. L. No. 89-711, 80 Stat. 1104 (1966).

42. S. REP. No. 89-1797, at 2 (1966), reprinted in 1966 U.S.C.C.A.N. $3663,3664$.

43. Id. at 1. See also H.R. ReP. No. 89-1892, at 5-6 (1966).

44. See S. ReP. No. 89-1797, at 2; H.R. ReP. No. 89-1892, at 8.

45. A "successive petition" is a habeas corpus petition raising identical grounds to those raised and dismissed with prejudice in a prior habeas corpus petition. Kuhlmann v. Wilson, 477 U.S. 436, 445 n.6 (1986). A "second petition" is a habeas corpus petition raising grounds that were available but not relied upon in a prior petition. Id. A second petition is also referred to as an "abuse-of-the-writ" petition. See McCleskey v. Zant, 499 U.S. 467, 488 (1991) (deseribing the different contexts in which the Court has applied the abuse-of-the-writ doctrine). For a further discussion of the rules regarding successive and second petitions, see infra Part II.B.2.

46. See 28 U.S.C. $\S 2244$ (b) (1970). 
provided that the state court findings of fact be presumed correct under most circumstances in federal habeas corpus proceedings. ${ }^{47}$ Like the 1948 Act, the 1966 amendments did not substantively alter the existing federal habeas corpus practice but merely codified Supreme Court rules.

\section{The Antiterrorism and Effective Death Penalty Act of 1996}

In the AEDPA, Congress enacted the most recent amendments to federal habeas corpus statutes. ${ }^{48}$ Effective as of April 24, 1996, the AEDPA was hastily passed in response to foreign and domestic terrorist attacks, particularly the 1993 bombing of the World Trade Center and the 1995 bombing of the Oklahoma City federal building. ${ }^{49}$ Riding on the public's sentiment for swift justice, Congress incorporated into the bill the most radical federal habeas corpus reform to date to "curb the abuse of the statutory writ of habeas corpus, and to address the acute problems of unnecessary delay and abuse in capital cases." ${ }^{\text {"50 }}$ Senator Hatch, who introduced the bill in the Senate, argued that it was "the only thing [Congress] could do to prevent even further suffering by [the victims of Oklahoma City bombing]." whelming majority votes on April 17 and April 18, 1996, respectively, ${ }^{52}$ just in time for the first anniversary of the Oklahoma City bombing. ${ }^{53}$

Delay in federal habeas corpus proceedings had long been a target for reform, ${ }^{54}$ but the sudden passage of the bill drew strong criticism. Critics condemned the adoption of the habeas corpus reform provisions in this emotionally charged atmosphere as political opportunism and expressed grave concern that the procedures so enacted would lead to executions and imprisonment of innocent people. ${ }^{55}$ Defenders of the bill insisted that habeas corpus reform was necessary to reduce frivolous appeals in federal

47. Id. $\$ 2254(\mathrm{~d})$. Subsection (d) enumerated circumstances that would overcome the presumption. See id. $\$ 2254$ (d)(1)-(8). For a more detailed discussion about the 1966 amendment on $\$ 2254$, see Weisselberg, supra note 17, at 151-54.

48. Pub. L. No. 104-132, 110 Stat. 1214 (1996). See also supra note 3.

49. For a description of the legislative history in the Senate, see generally Thomas C. Martin, The Comprehensive Terrorism Prevention Act of 1995, 20 Seton HALL LEGIS. J. 201 (1996).

50. H.R. CONF. REP. No. 104-51S, at 111 (1996), reprinted in 1996 U.S.C.C.A.N. $924,944$.

51. 141 CoNG. REC. S7479-03, at S7481 (daily ed. May 25, 1995) (statement of Sen. Hatch).

52. The Senate passed the bill by a 91-8 vote. 142 CoNG. REC. D322-02 (daily ed. Apr. 17, 1996) (Vote No. 71). The House passed the bill by a 293-133 vote. 142 Cong. Rec. D334-01 (daily ed. Apr. 18, 1996) (Roll No. 126).

53. The bombing took place on April 19, 1995.

54. In 1989 the Powell committee, formally called the Ad Hoc Committee on Federal Habeas Corpus in Capital Cases, proposed a six-month statute of limitations on the filing of federal habeas corpus petitions in capital cases to combat "unnecessary delay." Lewis F. Powell Jr., Report on Habeas Corpus in Capital Cases, 45 CRIM. L. Reporter 3239, 3239 (1989).

55. See, e.g., 141 Cong. REc. S7803-01, at S7815 (daily ed. June 7, 1995) (statement of Sen. Feingold) (objecting to the inclusion of habeas corpus reform provisions in the bill). 
courts $^{56}$ and to help President Clinton keep his promise to the families of Oklahoma City bombing victims that justice would be "swift, certam, and severe." 57

The AEDPA altered federal habeas corpus law in four ways that significantly restricted prisoners' access to the writ. First, it added special habeas corpus procedures for capital cases. ${ }^{58}$ Under the amended statute, states concerned with delays in federal habeas corpus proceedings may require death-row inmates to file their applications for writs of federal habeas corpus within 180 days of their conviction, so long as the states provide counsel for state postconviction proceedings. ${ }^{59}$

Second, the AEDPA raised an additional barrier to second or successive petitions by elevating the evidentiary standard by which "actual innocence" claims would be adjudicated from "more likely than not" to "clear and convincing." The judicially created actual-innocence doctrine allows a petitioner to bring his procedurally barred constitutional claims, including those barred by restrictions on second or successive petitions, through a probable showing of actual innocence. ${ }^{60}$ Under Supreme Court precedent, to establish actual innocence, "the petitioner must show that it is more likely than not that no reasonable juror would have convicted him in the light of the new evidence." ${ }^{61}$ When the AEDPA codified this judicial practice, it allowed an actual-innocence exception in second or successive petitions but only if the facts underlying the claim would "establish by clear and convincing evidence that, but for constitutional error, no reasonable factfinder would have found the applicant guilty of the underlying offense." ${ }^{962}$

Third, the AEDPA increased restrictions on the availability of evidentiary hearings in federal habeas corpus proceedings. Revised section 2254 provides that the presumption of correctness of the state's factfinding can only be rebutted by "clear and convincing evidence." ${ }^{363}$ Further, if the petitioner has failed to develop the factual basis of his constitutional claim in state court proceedings, federal courts may not hold evidentiary hearings on the same claim unless it relies on a newly recognized constitutional

56. See 141 Cong. REC. S7479-03, at S7479 (daily ed. May 25 1995) (statement of Sen. Hatch); Id. at $\mathrm{S} 7488$ (statement of Sen. Thurmond).

57. See 141 CoNG. REC. S7656-06, at S7657 (daily ed. June 5, 1995) (statement of Sen. Dole).

58. 28 U.S.C. $\$ \S 2261-2266(2000)$.

59. Id. $\$ \S 2261$ (b), 2263(a). Before the enactment of the AEDPA, there was no special federal habeas corpus procedure for capital cases; nor was there a statute of limitations on the filing of federal habeas corpus petitions. See infra Part III.A.

60. For a more detailed overview of the actual-innocence doctrine, see infra Part II.C.

61. Schlup v. Delo, 513 U.S. 298, 327 (I995). See also infra Part II.D.2.

62. 28 U.S.C. $\S 2244($ b)(2)(B)(ii) (2000) (governing state prisoners' second or successive petitions). A similar provision governing federal prisoners' second or successive petitions was provided in 28 U.S.C. $\S 2255(2000)$.

63. Id. §2254(e)(1). 
right or a newly discovered "factual predicate" that would establish the petitioner's actual innocence "by clear and convincing evidence."

Fourth, the AEDPA imposed a one-year statute of limitations on the filing of most federal habeas corpus petitions. ${ }^{65}$ Section 2244 (d) provides:

(1) A 1-year period of limitation shall apply to an application for a writ of habeas corpus by a person in custody pursuant to the judgment of a State court. The limitation period shall run from the latest of-

(A) the date on which the judgment became final by the conclusion of direct review or the expiration of the time for seeking such review;

(B) the date on which the impediment to filing an application created by State action in violation of the Constitution or laws of the United States is removed, if the applicant was prevented from filing by such State action;

(C) the date on which the constitutional right asserted was initially recognized by the Supreme Court, if the right has been newly recognized by the Supreme Court and made retroactively applicable to cases on collateral review; or

(D) the date on which the factual predicate of the claim or claims presented could have been discovered through the exercise of due diligence.

(2) The time during which a properly filed application for State post-conviction or other collateral review with respect to the pertinent judgment or claim is pending shall not be counted towards any period of limitation under this subsection. ${ }^{66}$

64. Id. $\$ 2254(\mathrm{e})(2)(\mathrm{B})$. Section 2254(e)(2) provides:

If the applicant has failed to develop the factual basis of a claim in State court proceedings, the court shall not hold an evidentiary hearing on the claim unless the applicant shows that-

(A) the claim relies on-

(i) a new rule of constitutional law, made retroactive to cases on collateral review by the

Supreme Court, that was previously unavailable; or

(ii) a factual predicate that could not have been previously discovered through the exercise of due diligence; and

(B) the facts underlying the claim would be sufficient to establish by clear and convincing evidence that but for constitutional error, no reasonable factfinder would have found the applicant guilty of the underlying offense.

Id. $\$ 2254(\mathrm{e})(2)$.

65. Id. $\S 2244$ (d) (governing state prisoners' habeas corpus petitions); Id. $\$ 2255$ (governing federal prisoners' habeas corpus petitions). A 180-day limitation is imposed on the filing of federal habeas corpus petitions by state death-row inmates in states that have opted to provide the inmates with assistance of counsel during state postconviction proceedings. Id. $\$ 2263$. This Comment will focus on the one-year statute of limitations in noncapital cases. For a discussion about the impact of the sixnonth statute of limitations in capital cases, see Mello \& Duffy, supra note 30.

66. 28 U.S.C. $\$ 2244$ (d) (2000). The Supreme Court has held that "pending," as used in section 2244(d)(2), covers the time between a lower state court's decision and the filing of a notice of appeal to a higher state court. Carey v. Saffold, 122 S. Ct. 2134, 2137-38 (2002). Califomia's collateral review system, however, differs from that of other states in that it does not require appellate review of a lower court determination but contenplates that a prisoner will file a new "original" habeas corpus petition at the appellate level. See $i d$. at 2139 . In addition, it determines the timeliness of each filing according to a 
Until 1996 no statute of limitations had ever restricted the filing of federal habeas corpus petitions. ${ }^{67}$

\section{B. Judicial Development of the Writ: The Supreme Court's Habeas Corpus Jurisprudence}

In 1807 Chief Justice Marshall declared in Ex parte Bollman that statutory law, rather than judicial application of common-law principles, governed the writ's existence and scope in the United States. ${ }^{68}$ Nevertheless, the Supreme Court has repeatedly either expanded or contracted the scope of habeas corpus pursuant to equitable principles ${ }^{69}$ and has acknowledged its "historic willingness to overturn or modify its earlier views of the scope of the writ, even where the statutory language authorizing judicial action has remained unchanged." 70 In fact, the Court has taken the lead in developing the modern writ. Until the enactment of the AEDPA, statutory amendments of federal habeas corpus law had largely been codifications of Supreme Court decisions. ${ }^{71}$ In sum, it is the interplay between federal statutes and common-law equitable principles that has defined the scope of federal habeas corpus review. ${ }^{72}$ Therefore, the remainder of this Section reviews the changes in the Court's habeas corpus jurisprudence over the years. A chronological account of the major developments in the Court's habeas corpus jurisprudence elucidates the framework in which the actualinnocence doctrine operates today.

Despite the Court's expansive reading of the Habeas Corpus Act of February 5, 1867 in Ex parte McCardle as bringing "within the habeas

\footnotetext{
"reasonableness" standard rather than a precise time limit. Id. The Court held that applications for state collateral review are "pending" in the California state courts for purpose of section 2244(d)(2) during the intervals between a lower court's determination and the filing of a further original state habeas corpus petition in a higher court. Id.

67. Before the enactment of the AEDPA, the discretionary "prejudicial delay" mle allowed courts to dismiss a petition as untimely, but only if it appeared that the state had been prejudiced in its ability to respond to the petition because of the petitioner's delay in filing. See Rule 9(a) of the Rules Governing Section 2254 Cases in the United States District Courts, Pub. L. No. 94-426, § 2(7), (8), 90 Stat. 1335 (1976) (current version at 28 U.S.C. $\$ 2254$ app. at R. 9(a) (2000)) [hereinafter Habeas Corpus R.]. For an account of deliberations leading to the adoption of Habeas Corpus Rule 9(a), see Sessions, supra note 17, at 1539-40. See also infra Part III.A.
}

68. 8 U.S. (4 Cranch) $75,93-94$ (1807).

69. Equitable principles include considerations to "reduce uncertainty, avoid unfair surprise, minimize disparate treatment of similar cases, ... help all litigants, including the State," and further the litigants' interests in finality. Lonchar v. Thomas, 517 U.S. 3 I4, 324 (I996).

70. Murray v. Carrier, 477 U.S. 478, 496 (1986) (quoting Wainwright v. Sykes, 433 U.S. 72, 81 (1977)). See also Jordan Steiker, Innocence and Federal Habeas, 41 UCLA L. REv. 303, 309 (1993) (characterizing the Court as having "consistently ignored statutory langnage in determining the availability of [the writ]").

71. See supra notes $38-40$ and accompanying text.

72. See Schlup v. Delo, 5 I3 U.S. 298, 319 n.35 (1995) ("This Court has repeatedly noted the interplay between statutory language and judicially managed equitable considerations in the development of habeas corpus jurisprudence."); see also 28 U.S.C. $\$ 2243$ (2000) (Federal courts shall "dispose of [habeas corpus petitions] as law and justice require."). 
corpus jurisdiction of every court and of every judge every possible case of privation of liberty contrary to the National Constitution, treaties, or laws," 73 its subsequent decisions seemed to limit the availability of the writ to cases where the sentencing court lacked jurisdiction. ${ }^{74}$ However, the Court, applying the Fifth Amendment's Due Process Clause, gradually extended the notion of jurisdiction beyond its original concept and found that the lower court lacked jurisdiction in instances where it sentenced a defendant twice for the same offense ${ }^{75}$ or prosecuted a defendant absent a grand jury indictment. ${ }^{76}$ In the early 1900 s, with the dramatic expansion of the due process concept and its application to the states via the Fourteenth Amendment, the scope of judicial inquiry in federal habeas corpus proceedings broadened rapidly. ${ }^{77}$ In the famous case of Frank $v$. Magnum, the Court held that federal habeas corpus relief would be available to state prisoners where the trial court failed to provide for adequate proceedings as guaranteed by the Fourteenth Amendment Due Process, such as in cases of mob-dominated trials. ${ }^{78}$ In later cases, the Court held that denial of due process would also include instances where the state knowingly used perjured testimony, ${ }^{79}$ or where the defendant was convicted without the

73. Ex parte McCardle, 73 U.S. (6 Wall.) 318, 325-26 (1867).

74. See, e.g., Ex parte Siebold, 100 U.S. 371, 375 (1879) (stating that habeas corpus cannot be used to attack a judgment of a court of competent jurisdiction because "a conviction and sentence by a court of competent jurisdiction is lawful cause of imprisonment"). For a discussion of the debate regarding whether the jurisdiction limitation originated from the common-law writ, see Weisselberg, supra note 17, at 139 n.40.

75. Ex parte Lange, 85 U.S. (18 Wall.) 163 (1873). The Fifth Amendment provides, in part, that no person shall "be subject for the same offence to be twice put in jeopardy of life or limb." U.S. CoNST. amend. V. Lange was convicted of appropriating to his own use postal mailbags, a federal offense punishable by either a fine of not more than two hundred dollars or imprisonment for not more than one year. Lange, 85 U.S. at 164. The lower court imposed on Lange both a two-hundred-dollar fine and one-year imprisonment. Id. The Supreme Court granted habeas corpus review and discharged Lange from imprisonment. $I d$. at 178 . It held that under the common law and the Constitution, where the statute only conferred power to punish by a fine or imprisonment, the lower court was without power to impose both a fine and imprisonment. Id.

76. Ex parte Wilson, 114 U.S. 417 (1885). The Fifth Amendment provides, in part, that "[n]o person shall be held to answer for a capital, or otherwise infamous crime, unless on a presentment or indictment of a Grand Jury." U.S. CoNST. amend. V. Wilson's offense was found to be an infamous crime, which therefore required indictment by a grand jury. Wilson, 114 U.S. at 429 . However, Wilson was prosecuted simply on a charge signed by a prosecutor. Id.

77. See DuKer, supra note 24 at $248-49$.

78. 237 U.S. 309, 355 (1915). Frank was convicted of murdering a young girl and sentenced to death in a trial dominated by a mob. Id. at 312 . The Georgia Supreme Court affirmed his conviction. Id. at 335 . While recognizing that a mob-dominated trial would be a violation of due process, the U.S. Supreme Court nevertheless denied habeas corpus relief because it concluded that the Georgia Supreme Court had considered and rejected all of the facts regarding the claim of mob domination, and therefore had provided its own corrective process. Id. at 335-36. For a detailed recounting of this case, see Leonard Dinnerstein, The Leo Frank Case (1968).

79. Mooney v. Holohan, 294 U.S. 103, 112-13 (1934). 
benefit of counsel. ${ }^{80}$ By 1942 the Court had expressly abandoned the jurisdiction limitation on the scope of cognizable habeas corpus claims. ${ }^{81}$

In 1953 the Court decided three cases known collectively as Brown $v$. Allen. ${ }^{82}$ Many consider the decisions to be the beginning of modern habeas corpus practice, particularly with respect to federal review of state criminal convictions. ${ }^{83}$ The Court made clear that all constitutional claims were grounds for federal habeas corpus relief irrespective of the sufficiency of the state process, even where the state's own corrective process was available and adequate. ${ }^{84}$ Justice Frankfurter, speaking for a five-member majority, reasoned that " $[t]$ he State court cannot have the last say when it, though on fair consideration and what procedurally may be deemed fairness, may have misconceived a federal constitutional right." ${ }^{95}$

The Warren Court (1953-1969) continued to use the writ "as its enforcement arm for the provisions of the Bill of Rights" and pushed the scope of cognizable federal habeas corpus claims to its outer limit. ${ }^{86}$ In

80. Smith v. O'Grady, 312 U.S. 329 (1941) (finding a due process violation where petitioner was convicted of burglary in state court after being tricked into pleading guilty without representation by counsel); Johnson v. Zerbst, 304 U.S. 458 (1938) (finding a due process violation where petitioner was convicted of counterfeiting in federal court without representation by counsel).

81. Waley v. Johnston 316 U.S. 101, 104-05 (1942). Waley petitioned for a writ of habeas corpus, alleging that he was coerced by federal agents into pleading guilty. Id. at 102 . The Court held that

the use of the writ in the federal courts to test the constitutional validity of a conviction for crime is not restricted to those cases where the judgment of conviction is void for want of jurisdiction of the trial court... [but also] extends to those exceptional cases where the conviction has been in disregard of the constitutional rights of the accused, and where the writ is the only effective means of preserving his rights.

Id. at 104-05.

82. 344 U.S. 443 (1953), superseded in part by 28 U.S.C. $\$ 2254$ (d) (1970), overruled in part by Williams v. Taylor, 529 U.S. 362 (2000). The three cases were Brown v. Allen, Speller v. Allen, and Daniels v. Allen. Petitioners were all North Carolina death-row inmates alleging, inter alia, racial discrimination in the selection of their juries. Id. at 466 (Brown), 477 (Speller), 482 (Daniels). After declaring a broad scope of federal review into state adjudications of federal constitutional claims, the Court nonetheless affirmed the lower courts' denial of federal habeas corpus relief, finding that (1) Brown was not denied due process in violation of the Fourteenth Amendment by the method of selecting grand and petit juries from lists limited to taxpayers, id. at 474 ; (2) Speller failed to demonstrate by clear and convincing evidence racial discrimination in the selection of the prospective jurors, id. at 481-82; and (3) Daniels and co-petitioner failed to use the state's available remedy (by failing to appeal within the 60-day limit applicable under state law) and thcrefore were barred from seeking federal review, id. at 487.

83. See Weisselberg, supra note 17, at 148 \& n.91; see also Staley v. Jones, 239 F.3d 769, 778 n.11 (6th Cir. 2001) (citing commentators' debates about whether Brown represented a fundamental change in federal habeas corpus review of state criminal convictions).

84. Brown, 344 U.S. at 458 (Reed, J.). Justice Reed, writing for the Court, stated that in federal habeas corpus review, the state court's adjudication of federal constitutional claims "is not res judicata." Id. Justice Frankfurter, in a separate opinion joined by four other Justices, observed that "even the highest State courts have failed to recognize violations" of federal constitutional rights. Id. at 511 (Frankfurter, J.).

85. Id. at 508 .

86. See Marshall J. Hartman \& Jeanette Nyden, Habeas Corpus and the New Federalism After the Antiterrorism and Effective Death Penalty Act of I996, 30 J. MARShall L. Rev. 337, 387 (1997). 
Jones v. Cunningham, the Court expanded the interpretation of the statutory "custody" prerequisite for habeas corpus relief to include prisoners who had been paroled. ${ }^{87}$ In Fay v. Noia, the Court departed from its precedents and made federal habeas corpus relief available to petitioners whose federal claims were dismissed by state courts on independent state procedural grounds. ${ }^{88}$ In Sanders v. United States, the Court declared that "[c]onventional notions of finality of litigation have no place where life or liberty is at stake and infringement of constitutional rights is alleged."

As the number of state prisoners filing for federal habeas corpus relief steadily increased, the seemingly endless reach of the writ of habeas corpus raised concerns about finality and state-federal comity..$^{90}$ Faced with heavily congested court dockets and a mounting pressure for habeas corpus reform, ${ }^{91}$ the Burger Court (1969-1986) and the Rehnquist Court (1986present) limited the availability of the writ by narrowing the scope of cognizable claims and raising procedural barriers. ${ }^{92}$ In Stone $v$. Powell, the Court eliminated Fourth Amendment violations by the state as a ground for

87. 371 U.S. 236, 243 (1963). Petitioner appealed from the district court's dismissal of his habeas corpus petition and was paroled by the Virginia Parole Board while his appeal was pending. Id. at 237 . The Court of Appeals for the Fourth Circuit dismissed the case as moot. Id. at 237-38. The Supreme Court reversed, holding that the restraints under the parole order "are enough to invoke the help of the Great Writ." Id. at 243.

88. 372 U.S. 391, 426 (1963), overruled in part by Coleman v. Thompson, 501 U.S. 722 (1991). Noia was convicted of felony murder in a New York state court. Id. at 394. He applied for a writ of habeas corpus, claiming that his conviction was based on a coerced confession (a charge the state later admitted). Id. The district court dismissed his petition on the ground that Noia had failed to seek a timely review by a state appellate court as required by 28 U.S.C. $\$ 2254$ (1952). Id. The court of appeals reversed. Id. The Supreme Court held that the section 2254 requirement to exhaust "the remedies available in the courts of the State" only requires exhaustion of state remedies still open to the applicant at the time he files his federal habeas corpus petition, and therefore Noia's failure to appeal to a state appellate court was not a failure to exhaust his remedies under section 2254. Id. at 399.

89. 373 U.S. 1, 8 (1963). Sanders was convicted of robbery of a federally msured bank under a guilty plea. $I d$. at 4 . He filed two motions for habeas corpus relief in the district court alleging that he was convicted without benefit of counsel. Id. The district court summarily dismissed his first motion for failing to plead facts. Id. at 5 . Sanders filed a second motion eight months later, alleging facts which, if true, might entitle him to relief. $I d$. at 4 . The district court dismissed his second petition on successive petition grounds, and the court of appeals affirmed. Id. at 5-6. The Supreme Court reversed, holding that a second petition may be denied only if the same ground was rejected on the merits in a prior application and "the ends of justice would not be served by reaching the merits of the subsequent application." Id. at 15.

90. See Henry J. Friendly, Is Innocence Irrelevant? Collateral Attack on Criminal Judgments, 38 U. CHI. L. REv. 142, 143 (1970) (noting the increase in the number of habeas corpus petitions filed by state and federal prisoners over a five-year period). But see Weisselberg, supra note 17, at 160-64 (arguing that the statistics should be viewed in the context of dramatic increase in state prison populations and the overall increase in the volume of civil litigation).

91. See, e.g., Friendly, supra note 90 (advocating federal habeas corpus reform).

92. See Mark M. Oh, Note, The Gateway for Successive Habeas Petitions: An Argument for Schlup v. Delo's Probability Standard for Actual Innocence Claims, 19 CARDOZo L. REv. 2341, 2344 n. 15 (1998) (citing the Burger and Rehnquist Courts' decisions that considerably narrowed the scope of federal habeas corpus review); see generally Friedman, supra note 39. 
federal habeas corpus relief..$^{93}$ In so holding, the Court emphasized that "in some circumstances considerations of comity and concerns for the orderly administration of criminal justice require a federal court to forgo the exercise of its habeas corpus power." 94

Concerns for comity and federalism have persisted in the Court's habeas corpus jurisprudence ever since. In 1991, the Court overruled Fay $v$. Noia in Coleman v. Thompson, holding that independent and adequate state grounds barred federal habeas corpus relief where "a state court declined to address a prisoner's federal claims because the prisoner had failed to meet a state procedural requirement." 95 The Court indicated that the "independent and adequate state ground" doctrine was grounded in concerns for comity and federalism. ${ }^{96}$ Tensions within habeas corpus jurisprudence continued to grow as the Court sought to balance concerns for comity, federalism, finality, and judicial resources against the writ's purpose of ensuring individual liberty, fundamental fairness, and the integrity of the criminal justice system.

II

\section{The Actual-InNocence Doctrine}

The actual-innocence doctrine emerged as a means to limit the scope of federal habeas corpus review. In the 1960s, when the scope of federal review was at its broadest, courts viewed the writ as a remedy for all constitutional wrongs regardless of the petitioner's innocence or guilt. Advocates for an innocence-focused review hoped to use actual innocence as a gatekeeper in restricting access to the writ.

As a variety of procedural barriers made filing federal habeas corpus petitions increasingly more difficult, the Court adopted the

93. 428 U.S. 465, 494 (1976). In Powell, state prisoners sought federal habeas corpus relief on the ground that evidence introduced at their trials was obtained through a search that violated their Fourth Amendment rights. Id. at 470, 472. The Court distinguished a Fourth Amendment claim of illegal search and seizure from other federal rights, noting that the exclusionary rule prohibiting admission of evidence obtained in an illegal search and seizure was not itself a constitutional right, but a judicially created means of effectuating the rights secured by the Fourth Amendment. Id. at 486 . The Court noted that the exclusionary rule was first applied to the states in criminal trials based primarily on a belief that it would deter future unlawful police conduct. Id. at 484 (citing Mapp v. Ohio, 367 U.S. $643,658(1961)$ ). The Court concluded that applying the exclusionary rule in federal habeas corpus reviews would not deter illegal searches and seizures. Id. at 494-95.

94. Id. at $478 \mathrm{n} .1 \mathrm{l}$ (quoting Francis v. Henderson, 425 U.S. 536 (1976)).

95. Coleman v. Thompson, 501 U.S. 722, 730 (1991). Coleman was convicted of capital murder and sentenced to death by a Virginia court. Id. at 726-27. After his direct appeal failed, Coleman filed a petition for writ of habeas corpus in the state court, in which he raised numerous federal constitutional claims. Id. at 727. The court dismissed his petition, and Coleman appealed to the Virginia Supreme Court. Id. A Virginia Supreme Court rule required that a notice of appeal be filed with the trial eourt within 30 days of final judgment. Id. Coleman's counsel did not file the notice of appeal until 33 days after the entry of final judgment. Id. The Virginia Supreme Court dismissed his appeal as untimely. Id. at 728 .

96. Id. at 728 . 
actual-innocence doctrine as a gateway through which petitioners who were able to show probable innocence could bring their procedurally barred constitutional claims. Thus, in the context of the dramatically more restrictive habeas corpus jurisprudence of the recent past, the actualinnocence doctrine has served to ensure access to the writ under limited circumstances.

Part II.A introduces Judge Friendly's article, Is Innocence Irrelevant?, which set forth the initial basis for the actual-innocence doctrine and heavily influenced the current Court's innocence-focused habeas corpus jurisprudence. Part II.B describes judicially created procedural barriers to federal habeas corpus review. Part II.C reviews the Court's application of the actual-innocence doctrine as a gateway through these procedural barriers. Finally, Part II.D discusses the standard of proof for actual-innocence claims.

\section{A. The Relevance of Innocence}

An innocence-focused federal habeas corpus review was originally proposed not to extend the reach of the writ but to limit it. If the purpose of the writ is to defend life and liberty by ensuring the constitutionality of the process, then the convicted's innocence or guilt should logically be irrelevant. When the Great Writ was at its broadest reach in the 1960 s, the Court viewed the writ as a remedy for all constitutional wrongs, regardless of innocence or guilt. ${ }^{97}$ However, concerns for comity, federalism, finality, and judicial resources have shifted the emphasis of federal habeas corpus practice to innocence or guilt.

Judge Friendly's influential article, Is Innocence Irrelevant?, published in 1970, helped shape the current innocence-focused habeas corpus jurisprudence. ${ }^{98}$ In his article, Judge Friendly argued that postconviction collateral attack should only be available when "the prisoner suppleinents his constitutional plea with a colorable claim of innocence."99 Judge Friendly contended that the states' interests in deterring criminal activities,

97. See Smith v. Bennett, 365 U.S. 708, 712-13 (1961) (describing the writ as "the common law world's 'freedom writ' by whose orderly processes the production of a prisoner in court may be required and the legality of the grounds for his incarceration inquired into, failing which the prisoner is set free").

98. Friendly, supra note 90. See also Kuhlmann v. Wilson, 477 U.S. 436, 454 \& n.17 (1986) (citing Judge Friendly's article for the proposition that allowing guilty defendants to bring postconviction collateral attack will frustrate states' interest in deterrence and finality and adopting Judge Friendly's proposal on the standard of proof for actual innocence claims). Compare with Paul M. Bator, Finality in Criminal Law and Federal Habeas Corpus for State Prisoners, 76 HARv. L. Rev. 441 (1963) (articulating another influential reconstruction of habeas corpus law to limit state prisoners' access to federal habeas corpus review). But see James S. Liebinan, Apocalypse Next Time?: The Anachronistic Attack on Habeas Corpus/Direct Review Parity, 92 CoLum. L. Rev. 1997, 2041-54 (1992) (criticizing Bator's thesis about the writ's history as flawed).

99. Friendly, supra note 90, at 142 . 
preventing long delays that result in evidentiary difficulties, preserving judicial resources, and achieving finality justify limiting access to the writ. ${ }^{100} \mathrm{He}$ noted that "the one thing almost never suggested on collateral attack is that the prisoner was innocent of the crime"101 and reasoned that a prerequisite of a "colorable showing of innocence" would "enable courts of first instance to screen out rather rapidly a great multitude of applications not deserving their attention and devote their time to those few whcre injustice may have been done." ${ }^{\prime 102} \mathrm{He}$ argued that limited access to scarce judicial resources would allow the courts to hear those occasional meritorious petitions, rather than having those petitions "buried in a flood of worthless ones." 103 In clarifying the meaning of "a colorable showing of actual innocence," Judge Friendly proposed a probability standard:

[T] he petitioner for collateral attack must show a fair probability that, in light of all the evidence, including that alleged to have been illegally admitted (but with due regard to any unreliability of it) and evidence tenably claimed to have been wrongly excluded or to have become available only after the trial, the trier of the facts would have entertained a reasonable doubt of his guilt. ${ }^{104}$

Judge Friendly concluded that innocencc is relevant to the extent that collateral attack by a prisoner should be confined to claims that cast "some shadow of doubt upon his guilt."105 Under Judge Friendly's proposal, constitutional due process rights deserve protection by way of the writ of habeas corpus only for those who are probably innocent.

\section{B. Procedural Barriers to Federal Habeas Corpus Review}

Access to the writ has always been limited. In seventeenth century England, the writ was "issued where the ordinary legal remedies were unavailable or inadequate."106 Incorporating this principle into the American legal system, the Supreme Court has established a number of procedural barriers to federal habeas corpus review.

\section{The Exhaustion Doctrine and the Procedural-Default Rule}

Guided by the principle of comity, the Court first created the exhaustion doctrine in Ex parte Royall, which gavc federal courts discretion to refuse a habeas corpus application from a state prisoncr challenging the

100. See id. at $146-49$.

101. Id. at 145 .

102. Id. at 150 .

103. Id. at 149 .

104. Id. at 160 .

105. Id. at 172 (quoting Kaufman v. United States, 394 U.S. 217, 235 (1969) (Black, J., dissenting), overruled by Stone v. Powell, 428 U.S. 465 (1976)).

106. DuKER, supra note 24, at 4. 
constitutionality of his state custody in advance of his trial. ${ }^{107}$ In Ex parte Fonda, the Court expanded the exhaustion doctrine, requiring state prisoners who had state appellate processes available to them to first exhaust those processes. ${ }^{108}$

Related to the exhaustion doctrine is the procedural-default rule. This rule bars federal review of a state prisoner's federal constitutional claims denied by the state court for failure to comply with a state procedural requirement, such as the form or timing of a post-trial motion. The Court's applications of this rule at different time periods illustrate the tensions among the various equitable primciples operating in the habeas corpus framework. Brown v. Allen held that state prisoners who had failed to appeal within the sixty-day limit applicable under state law were deemed to have failed to exhaust the state's available remedies and were therefore barred from seeking federal review. ${ }^{109}$ However, in Fay v. Noia, the Court held that a state prisoner's failure to seek : timely review by a state appellate court was not a failure to exhaust state remedies under section $2254 .{ }^{110}$ To promote comity and finality, the Rehnquist Court subsequently overruled Noia in Coleman v. Thompson and reestablished the proceduraldefault rule. ${ }^{111}$ As the law now stands, a state prisoner may be barred from seeking federal habeas corpus relief if the state court has denied his federal claim on independent and adequate state procedural grounds. ${ }^{112}$

\section{Rules Disfavoring Successive or Second Petitions}

Although the Court proclaimed in Sanders v. United States that "[c]onventional notions of finality of litigation have no place where life or liberty is at stake and infringement of constitutional rights is alleged," 113 the noble goal of safeguarding an individual's life and liberty has yielded to the public's interest in finality. Federal district courts may dismiss a prisoner's subsequent habeas corpus petitions on the ground that the petitioner is abusing the writ. ${ }^{114}$ The Court has identified two categories of abusive petitions that may warrant dismissal: petitions that raise identical grounds to those raised and dismissed on merits in a prior habeas corpus petition (successive petitions) and petitions that raise grounds that were previously available but not relied upon (second petitions). ${ }^{115}$ The rules against successive petitions are employed to prevent prisoners from

107. 117 U.S. $241,252-53$ (1886).

108. 117 U.S. 516 (1886). Congress codified the exhaustion doctrine in the 1948 Act. See also supra text accompanying notes $39-40$.

109. 344 U.S. 443, 487 (1953). See also supra note 82.

110. 372 U.S. 391,399 (1963). See also supra note 88.

111. 501 U.S. 722, 730 (1991). See also supra note 95.

112. Coleman, 501 U.S. at 730.

113. 373 U.S. 1,8 (1963).

114. 28 U.S.C. $\$ 2244($ b) (2000). See also Habeas Corpus R. 9, supra note 67.

115. Kuhlmann v. Wilson, 477 U.S. 436, 445 n.6 (1986). 
relitigating the same federal claims; the rules against second petitions aim to prevent prisoners from "strategically" delaying or inexcusably neglecting the filing of the claims, which might undermine the state's interest in finality and prejudice the state's ability to respond. ${ }^{116}$

\section{The Cause-and-Prejudice Standard}

If a state prisoner's constitutional claims were procedurally defaulted on independent and adequate state grounds, he is barred from seeking federal habeas corpus review unless he can establish both "cause" for failing to comply with the state procedural rules and "actual prejudice" suffered as a result of the alleged constitutional errors. ${ }^{117}$ This cause-and-prejudice standard also determines whether a court will excuse a habeas corpus petitioner's failure to raise an available claim until the "second petition." 118 Cause requires a showing that "some objective factor external to the defense impeded counsel's efforts' to raise the claim." "119 Objective factors that may constitute cause include interference by officials that makes compliance with the state's procedural rule impracticable, the unavailability of the factual or legal basis for a claim, and ineffective assistance of counsel. ${ }^{120}$ To demonstrate prejudice, a prisoner must show "not merely that the errors at his trial created a possibility of prejudice, but that they worked to his actual and substantial disadvantage, infecting his entire trial with error of constitutional dimensions." 21

The cause-and-prejudice standard creates a nominal exception to the procedural barriers. The Court's application of the rule strongly suggests that there are few circumstances under which a habeas corpus petitioner can overcome a procedural barrier. For example, in Murray v. Carrier, the Court held that counsel's failure either to recognize the factual or legal basis for a claim or to raise the claim despite recognizing it, does not constitute cause for a procedural default. ${ }^{122}$ The Court's stringent application of

116. McCleskey v. Zant, 499 U.S. 467, 489-90 (1991).

117. See, e.g., Francis v. Henderson, 425 U.S. 536, 542 (1976) (finding that the state prisoner's challenge to the unconstitutional composition of the grand jury was barred because he failed to show cause for failing to make a timely objection in the state court and actual prejudice).

118. McCleskey, 499 U.S. at $490-91$.

119. Id. at 493 (quoting Murray v. Carrier, 477 U.S. 478, 488 (1986)).

120. Id. at 494 .

121. United States v. Frady, 456 U.S. 152, 170 (1982).

122. 477 U.S. 478, 486 (1986). In Carrier, the Court held that any attorney error short of ineffective assistance of counsel does not constitute cause for a procedural default. Id. at 479 . Carrier was convicted of rape by a Virginia jury. On direct appeal to the Virginia Supreme Court, his trial counsel failed to include in the petition, by an apparent oversight, a claim that the defendant had been denied due process by the prosecution's withholding of the victim's statements. $I d$. at 482 . The state court denied Carrier's subsequent state habeas corpus petition on the ground that a Virginia Supreme Court rule barred him from raising the due process discovery claim on collateral review if he failed to raise it on direct appeal. Id. at 483 . The U.S. Supreme Court found that counsel's performance on direct 
the cause-and-prejudice exception is consistent with its view that the rule is premised on concerns for comity and finality rather than on concerns for the petitioner's constitutional rights. ${ }^{123}$

\section{Actual Innocence as a Gateway Through the Procedural Barriers}

The actual-innocence doctrine, as advocated by Judge Friendly, was originally intended to filter out frivolous habeas corpus petitions and to promote coinity and finality. ${ }^{124}$ In 1986 the doctrine acquired a new function: The Supreme Court approved its use as a means by which prisoners could bring procedurally barred claims. Creating an exception to the stringent application of the cause-and-prejudice standard, the Court permitted federal habeas corpus review of a petitioner's otherwise procedurally barred constitutional claims in the absence of cause by "a colorable showing of actual innocence."125

The Court recognized that in "appropriate cases' the principles of comity and finality that inform the concepts of cause and prejudice 'must yield to the imperative of correcting a fundannentally unjust incarceration."'126 Whether the incarceration is "fundamentally unjust" almost always centers on the innocence or guilt of the prisoner rather than on the constitutionality of the process. ${ }^{127}$ In Murray v. Carrier, the Court stated that "where a constitutional violation has probably resulted in the conviction of one who is actually innocent, a federal habeas court may grant the writ even in the absence of a showing of cause for the procedural default" to prevent a "miscarriage of justice."128 On the same day Carrier was decided, the Court articulated an identical actual-innocence exception to the bar against successive petitions in Kuhlmann $v$. Wilson. ${ }^{129}$ In a

appeal was not "so deficient as to make out an ineffective assistance claim," and therefore did not constitute cause to excuse a procedural default. Id. at 497.

123. See id. at 495 (observing that the principles of comity and finality informed the concepts of cause and prejudice).

124. See supra Part II.A.

125. Kuhlmann v. Wilson, 477 U.S. 436, 454 (1986).

126. Carrier, 477 U.S. at 495 (quoting Engle v. Isaac, 456 U.S. 107, 135 (1982)).

127. For a collection of articles challenging the Court's innocence-focused habeas corpus reform, see Steiker, supra note 70, at 305 n. 12 .

128. Carrier, 477 U.S. at 495-96. See supra note 122 for a description of the case. For a discussion about the historical conceptions of the "miscarriage of justice" term of art in habeas corpus jurisprudence, see Steiker, supra note 70, at 338-42.

129. Wilson, 477 U.S. at 454. Petitioner Wilson's incriminating statements to a jailhouse cellmate who was actually a police informant were admitted at trial. 1 d. at 439 . Wilson was subsequently convicted of murder by a New York jury. Id. at 440. In his first federal babeas corpus petition, Wilson claimed that his statements to the informant were obtained pursuant to police investigative methods that violated his Sixth Amendment right to counsel. Id. at 44I. The district court dismissed his claim on the merits, and the dismissal was affirmed by the court of appeals. $I d$. Wilson raised the same claim in his second federal habeas corpus petition following the Court's decision in United States $v$. Henry, 447 U.S. 264 (1980) (suppressing statements made to a paid jailhouse informant). Wilson, 477 U.S. at 442. The Supreme Court found that Wilson's second federal habeas corpus petition was barred on 
plurality opinion, the Court noted that "ends of justice" require federal courts to entertain a successive petition "only where the prisoner supplements his constitutional claim with a colorable showing of factual innocence. ${ }^{\prime 130}$ Five years later, in McCleskey v. Zant, the Court approved an actual-innocence exception to bars against second petitions so as to serve the ends of justice. ${ }^{131}$ In sum, the Court eventually recognized an actual-innocence exception to all the postconviction procedural barriers it had instituted.

The actual-innocence doctrine thus became a safety valve that ensures the availability of the writ to those who are probably innocent. However, the Court emphasized that actual innocence "is not itself a constitutional claim, but instead a gateway through which a habeas petitioner must pass to have his otherwise barred constitutional claim considered on the merits." 132 Thus, freestanding claims of actual innocence are insufficient to overcome the procedural bar; they must be accompanied by an independent claim that a preconviction constitutional error occurred. ${ }^{133}$ As a safety valve, the doctrine plays an integral role in achieving a delicate balance between conflicting equitable principles. An innocence-focused habeas corpus review considerably narrows the reach of the writ in exchange for comity and finality. At the same time, the actual-innocence doctrine allows limited access to federal review in exceptional cases, thereby affirming, at least on its face, the principles of individual liberty, fundamental fairness, and the integrity of the criminal justice system.

\section{The Standard of Proof for Actual-Innocence Claims}

Prior to the enactment of the AEDPA, the Supreme Court applied a differential standard of proof for innocence-based claims, depending on whether the petitioner claimed that he was innocent of the punishment (i.e. receiving an unfair sentence) or innocent of the crime charged (i.e. actually innocent). The former was held to a clear-and-convincing-evidence standard of proof while the latter could be established by a probability standard of proof. The AEDPA elevated the standard of proof for "innocent of the crime" claims to a clear-and-convincing-evidence standard.

successive-petition grounds, and concluded that "ends of justice" would not be served to allow his succcssive petition in view of overwhelming evidence of his guilt. Id. at 455 .

130. Id. at 454 .

131. 499 U.S. 467,495 (1991).

132. Herrera v. Collins, 506 U.S. 390,404 (1993).

133. Id. at 416. For a discussion on whether federal habeas corpus law should recognizc "bare innocence" claims (innocence claims unaccompanied by constitutional claims), see Steiker, supra note 70. 
1. Sawyer v. Whitley: The Clear-and-Convincing-Evidence Standard of Prooffor "Innocent of the Punishment" Claims

Although courts and commentators almost always discuss "actual innocence" in an "innocent of the crime" context, in Sawyer $v$. Whitley, the petitioner, a Louisiana death-row mmate, did not claim that he was actually iunocent of the crime but rather that he was innocent of his punishment. ${ }^{134}$ He argued that but for the police's failure to produce exculpatory evidence and but for his counsel's failure to introduce medical records establishing his mental instability in the sentencing phase, no reasonable juror would have found him eligible for the death penalty under Louisiana law. ${ }^{135}$ In rejecting both claims as short of establishing innocence, ${ }^{136}$ the Court promulgated a "clear and convincing evidence" standard for a petitioner's innocence-based claims, holding that "one must show by clear and convincing evidence that, but for a constitutional error, no reasonable juror would have found the petitioner eligible for the death penalty under the applicable state law." 137 The Court did not make a distinction between "innocent of the punishment" claims and "innocent of the crime" claims. Rather, the Court categorically stated that "the exception for 'actual innocence' is a very narrow exception" and requires a determination by relatively objective standards for it to be workable. ${ }^{138}$ Sawyer left unclear whether the same standard of proof would apply when evaluating an actual-innocence claim where the petitioner claims that he is innocent of the crime of which he was convicted.

\section{Schlup v. Delo: The Probability Standard of Proof for Actual- Innocence Claims}

In Schlup v. Delo, the Court distinguished Sawyer and declared a probability standard for actual-innocence claims. ${ }^{139}$ Schlup was convicted of murdering a fellow inmate and sentenced to death. ${ }^{140}$ In his second federal habeas corpus petition, Schlup claimed that he was actually innocent of the crime and therefore should be allowed to present his otherwise procedurally barred constitutional claims: ineffective assistance of trial counsel and failure to disclose exculpatory evidence by the state. ${ }^{141}$ In support of his actual-innocence claim, Schlup submitted affidavits from a former lieutenant at the prison, who recited in detail his encounter with Schlup

\footnotetext{
134. 505 U.S. 333 (1992).

135. Id. at $347-48$.

136. Id at 348-49.

137. Id. at 336 .

138. Id. at 341 .

139. 513 U.S. $298,325-27$ (1995).

140. Id. at 301 .

141. Id. at 307.
} 
around the time the murder took place, ${ }^{142}$ and from fellow inmates who either witnessed the assault or provided specific information about the crucial time frame of the events related to the assault. ${ }^{143}$ Schlup argued that all the newly submitted exculpatory evidence was unavailable at trial either due to concealment by the prosecution or due to trial counsel's failure to effectively interview or examine the witnesses. ${ }^{144}$ Schlup contended that the affidavits, along with the evidence presented at trial, would have established his innocence. ${ }^{145}$ Relying on Sawyer, the district court found that Schlup failed to establish actual innocence by clear-and-convincingevidence and dismissed his petition without reaching the merits of his constitutional claiins. ${ }^{146}$

The Eighth Circuit affirmed. However, the Supreme Court, in a fivefour decision, held that the Sawyer standard did not adequately protect against the miscarriage of justice that would result from executions of the innocent. ${ }^{147}$ The Court reasoned that when the claim presented is that constitutional error has resulted in the conviction of one who is actually innocent, the probability standard expressed in the dicta in Murray v. Carrier ${ }^{148}$ and the plurality opinion in Kuhlmann $v$. Wilson ${ }^{149}$ struck a proper balance between "the societal interests in finality, comity, and conservation of scarce judicial resources" and "the individual interest in justice." 150 In distinguishing Sawyer, the Court differentiated between being innocent of the punishment and being innocent of the crime, holding that in the latter cases, "a somewhat less exacting standard of proof" should apply. ${ }^{151}$ The Court concluded: "To establish the requisite probability, the petitioner must show that it is more likely than not that no reasonable juror would have convicted him in the light of the new evidence."152

\section{The AEDPA's Clear-and-Convincing-Evidence Standard of Proof for Actual-Innocence Claims in Second and Successive Petitions}

The AEDPA superceded Schlup and imposed a clear-and-convincingevidence standard on actual innocence claims based on newly discovered evidence in second and successive petitions. ${ }^{153}$ By anending section 2244(b), the Act effectively codified the judicial doctrine of actual

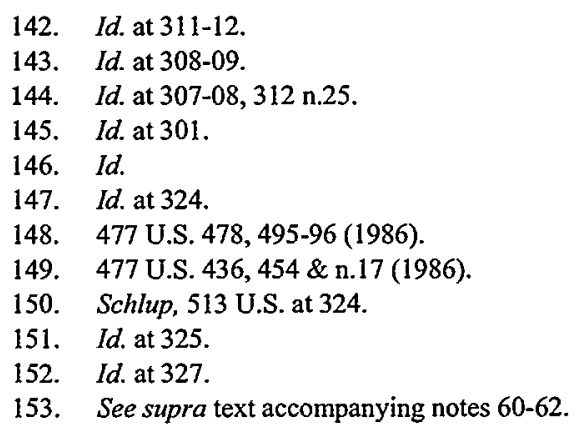


innocence in the context of second or successive petitions while simultaneously requiring a higher standard of proof than did Schlup. Under the Act, a prisoner filing a second or successive petition claiming actual innocence (i.e. innocent of the crime) must prove "by clear and convincing evidence that, but for constitutional error, no reasonable factfinder would have found the applicant guilty of the underlying offense." 154 In passing the bill, the majority of Congress simply disregarded Schlup without addressing any of the concerns the Court had raised. . $^{15}$

\section{III}

\section{CRitique of the AEDPA's Statute of Limitations}

Before the enactment of the AEDPA, no statute of limitations had ever been applied to federal habeas corpus proceedings. To the contrary, the Supreme Court had declared that "habeas corpus provides a remedy for jurisdictional and constitutional errors at the trial, without limit of time."156 As Justice Harlan pronounced in Chessman v. Teets,

the overriding responsibility of this Court is to the Constitution of the United States, no matter how late it may be that a violation of the Constitution is found to exist. This Court may not disregard the Constitution because an appeal... has been made on the eve of execution. We must be deaf to all suggestions that a valid appeal to the Constitution, even by a guilty man, comes too late, because courts, including this Court, were not earlier able to enforce what the Constitution demands. The proponent before the Court is not the petitioner but the Constitution of the United States. ${ }^{157}$

Prior to the AEDPA, the only time constraint upon the filing of a federal habeas corpus petition was Rule 9(a) of the Rules Governing $\S 2254$ Cases in the United States District Courts ("Habeas Corpus Rules"), which provided: "A petition may be dismissed if it appears that the state ... has been prejudiced in its ability to respond to the petition by delay in its filing."158 While the current Court may disagree with Justice Harlan's expansive view of the scope of the writ, it has nonetheless considered the impact of any time constraint on the availability of the writ to be grave. Accordingly, the Court has construed Rule 9(a) liberally to ensure that it does not entirely deprive a petitioner of his right to apply for the writ. Less

154. 28 U.S.C. $\$ 2244$ (b)(2)(B)(ii) (2000). On its face, the AEDPA does not recognize "innocent of the punishment" claims as an exception to the bar against second or successive petitions.

155. Relying on Schlup, Senator Levin proposed to amend the bill to lower the standard of proof to the probability standard. See 141 CoNG. REC. S7803-1, at S7823 (daily ed. June 7, 1995) (statement of Sen. Levin). However, Senator Hatch dismissed Levin's proposal as creating loopholes and allowing liberal judges to overturn a death sentence for ideological reasons. See id. at S7825 (statement of Sen. Hatch).

156. United States v. Sinith, 331 U.S. 469,475 (1947).

157. 354 U.S. 156, 165 (1957).

158. Habeas Corpus R. 9(a), supra note 67. 
than one month before the enactment of the AEDPA, in Lonchar $v$. Thomas, the Court considered whether Rule 9(a) should be applied to a first habeas corpus petition. ${ }^{159}$ The Court held that a first federal habeas corpus petition should not be dismissed because of "special ad hoc 'equitable' reasons not encompassed within the framework of Rule 9(a) of the Habeas Corpus Rules." 160 The Court reasoned that "[d]ismissal of a first federal habeas petition is a particularly serious matter, for that dismissal denies the petitioner the protections of the Great Writ entirely, risking injury to an important interest in human liberty."161 The Court also recognized that first petitions generally pose less threat to the state's interest in finality and are more likely to lead to the discovery of unconstitutional convictions. ${ }^{162}$ The Court, mindful of the reform bills under deliberation in Congress that included a statute of limitations on federal habeas petitions, ${ }^{163}$ cautioned that because "the interest in permitting federal habeas review of a first petition is quite strong, ... it is particularly important that any rule that would deprive inmates of all access to the writ should be both clear and fair." 164 This warning against an ambiguous and unfair statute of limitations apparently had little impact on Congress as it rushed to pass the AEDPA.

\section{A. Access to the Writ Unduly Restricted}

A one-year statute of limitations on the filing of federal habeas corpus petitions, let alone a six-month one in capital cases, ${ }^{165}$ effectively precludes the filing of most federal habeas petitions, including first petitions. A time period this short blatantly ignores the realities of postconviction collateral litigations, particularly with regard to state prisoners. Significantly, states are not required to provide counsel in postconviction collateral proceedings. ${ }^{166}$ It is therefore not surprising that, according to a study conducted by

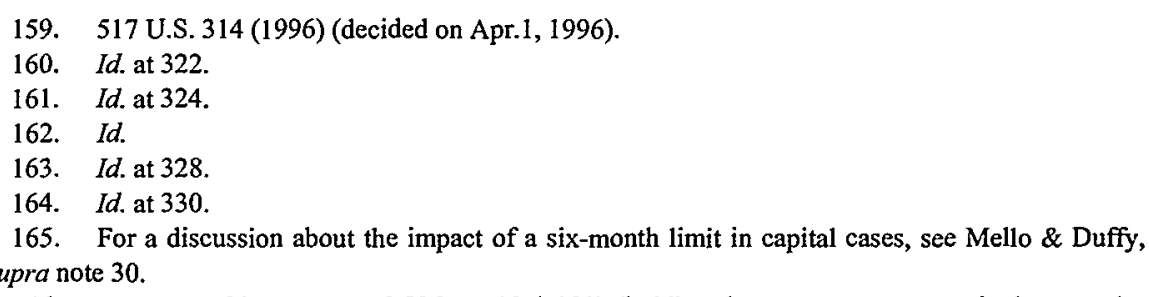

166. Murray v. Giarratano, 492 U.S. 1, 10 (1989) (holding that states are not required to appoint counsel for indigent death-row inmates seeking state postconviction relief); Ross v. Moffitt, 417 U.S. 600,610 (1974) (holding that due process did not require a state to provide indigent defendant with counsel on his discretionary appeal to the state supreme court). Congress also eliminated funding for death penalty resource centers, which provided counsel to the condemned in habeas corpus proceedings. See Stephen B. Bright, Is Fairness Irrelevant?: The Evisceration of Federal Habeas Corpus Review and Limits on the Ability of State Courts to Protect Fundamental Rights, 54 WASH. \& LEE L. Rev. 1, 4 (1997). 
the U.S. Department of Justice, Bureau of Justice Statistics (the "BJS"), prisoners were acting pro se in $93 \%$ of the sampled habeas corpus cases. ${ }^{167}$

One year is insufficient time for a confined inmate to prepare and file a meaningful habeas corpus petition that would escape the fatal traps of the exhaustion doctrine, the procedural-default doctrine, and the second and successive petitions doctrines. Many inmates are uneducated, mentally impaired, or both. ${ }^{168}$ According to the statistics compiled in 1994 by the BJS, $47 \%$ of the adult inmates in the United States had less than a high school education and only $16 \%$ had some collegc education. ${ }^{169}$ For most inmates, "attempting to read a law book would be akin to attempting to read a book written in a foreign langnage." 170 Access even to the fullest law library has been described as "a useless and meaningless gesture in terms of the great mass of prisoners"171 and compared to "furnishing medical services through books like 'Brain Surgery Self-Taught,' or 'How to Remove Your Own Appendix,' along with scalpels, drills, hemostats, sponges, and sutures." 172 It is both unrealistic and unfair to expect an inmate to fully understand the legal remedies he might have or the legal consequences he might face upon reading an outdated book on federal habeas corpus practice. That is assuming, of course, that the inmate had access to an operating prison law library. In Anthony Burton's case, the prison was unable to provide him with a book, any book, on habeas corpus practice.

Even if an inmate without a high-school education were able to comprehend current laws and procedural rules on habeas corpus practice and fully digest the trial transcript and record, and even if he had access to the often voluminous trial record from his prison cell, effective postconviction collateral attacks often require a reinvestigation of the case. Reinvestigation is especially crucial where the claims must rely on new evidence. In cases involving claims of ineffective assistance of counsel or prosecutorial misconduct, it is those facts not already established in the record that are the most relevant. Yet few inmates have access to the outside resources

167. Roger A. Hanson \& Henry W.K. Daley, federal habeas Corpus Review: Challenging State Court Criminal Convictions 14 (U.S. Dep't of Justice Bureau of Justice Statistics Publ'n, Sept. 1995), available at http://www.ojp.usdoj.gov/bjs/abstract/fhcrcscc.htm. ln another $3 \%$ of the cases, "the prisoners either retained private counsel or were represented by the American Civil Liberties Union or a prisoners' rights group." Id. The study covered eighteen federal district courts located in nine selected states, which handle roughly half of the nation's federal habeas corpus petitions filed each year.

168. See Mello \& Duffy, supra note 30, at 481-84.

169. James P. LyNCh ET AL., Profile OF INMATES IN THE UNTted STATES AND IN ENGLAND AND WALES, I99I, at 14 (U.S. Dep't of Justice Bureau of Justice Statistics Publ'n, Oct. 1994), available at http://www.ojp.usdoj.gov/bjs/abstract/walesus.htm.

170. Mello \& Duffy, supra note 30, at 481 (quoting Hooks v. Wainwright, 536 F. Supp. 1330, 1344 (M.D. Fla. 1982), rev'd on other grounds, 775 F.2d 1433 (I1 th Cir. 1985), cert. denied, 479 U.S. $913(1986))$.

171. Id. at 485 (quoting Falzerano v. Collier, 535 F. Supp. 800,803 (D.N.J. 1982)).

172. Id. 
necessary to engage in further factfinding. Without the help of his attorney, Anthony Burton would have had logistical and financial difficulties in securing a handwriting expert to establish the authenticity of Ronald Washington's recantation letter and locating and interviewing Washington, who was himself in prison.

Even for inmates who have assistance of counsel during their postconviction proceedings, the one-year time period is unrealistic. Most of these attorneys represent prisoners on a pro bono basis. As a pragmatic matter, it is impossible for them to devote all their time and energy to preparing for complex and prolonged postconviction litigations. After a long search, Anthony Burton was lucky to find an attorney who agreed to assist him pro bono. However, it took his attorney more than a year to file for state postconviction relief in the California Supreme Court. And this attorney, who eventually abandoned Burton, failed to notify him of the denial of his state petition. Courts have generally held that counsel's mistake would not constitute extraordinary circumstances required for equitable tolling of the one-year limitations period. ${ }^{173}$

Although the AEDPA tolls the statute of limitations while a state postconviction proceeding is pending, ${ }^{174}$ inmates are often transferred from one prison facility to another ${ }^{175}$ and may not be able to learn about the state court's final denial until much later, at which point the balance of the oneyear time limit is already ticking away. Burton faced this predicament. The California Supreme Court denied him relief on January 14, 1998. According to the district court's calculation, Burton had until February 17, 1998, to file his federal habeas corpus petition. However, because his attorney ceased to assist him midway, and because he was being transferred between prisons, he did not learn about the court's decision until March 21, 1998.

173. See, e.g., Smaldone v. Senkowski, 273 F.3d 133, 138-39 (2d Cir. 2001) (holding that attorney's error in construing the AEDPA's statute-of-limitations provision did not rise to the 'extraordinary' circumstances required for equitable tolling); Harris v. Hutchinson, 209 F.3d 325, 330 (4th Cir. 2000) (holding that attorney's apparently innocent misreading of the one-year statute-oflimitations provision did not justify equitable tolling); Taliani v. Chrans, 189 F.3d 597, 597-98 ( 7 th Cir. 1999) (holding that attorney's mistake in calculating the time period did not toll the one-year limitations).

174. 28 U.S.C. $\S 2244$ (d)(2) (2000). See also Carey v. Saffold, 122 S. Ct. 2134, 2137-38 (2002); supra note 66 (discussing Carey).

175. See, e.g., Edwards v. Logan, 38 F. Supp. 2d 463, 465 n.l (W.D. Va. 1999) ("The states frequently transfer prisoners pursuant to interstate compacts, for reasons of overcrowding or particular inmate needs.") (citing Olin v. Wakinekona, 461 U.S. 238, 245-46 (1983)); Peterson v. Davis, 415 F. Supp. 198, 200 (D.C. Va. 1976) ("Prisoners are often transferred from one institution to another in order to prevent violence and to protect the prisoner."). 


\section{B. Purpose of the AEDPA Not Served}

In view of its draconian consequences, it is especially disturbing that the statute of limitations imposed by the AEDPA has no policy justification. The stated purpose of the AEDPA's habeas corpus reform provisions is "to curb the abuse of the statutory writ of habeas corpus, and to address the acute problems of unnecessary delay and abuse in capital cases."176 However, according to the 1995 study by the BJS, only $8 \%$ of the dismissed federal habeas corpus petitions were on second or successive petition grounds, while $57 \%$ were dismissed for failure to exhaust state remedies and $12 \%$ on procedural default grounds. ${ }^{177}$ Moreover, the statute of limitations neither curbs abuse nor addresses the problem of delay.

Some commentators have expressed concern that attorneys would manipulate the system by "deferring collateral attack until the eve of execution." 178 However, it is hard to imagine that a competent attorney would risk his client's life just to preserve a claim for the eve of execution, or that a condemned inmate would "strategically" withhold claims. Even if we accept the notion that it is common for a death-row mmate to delay his federal habeas corpus petition until the eve of execution just to extend his time on earth (or, more accurately, on death row), this motive cannot possibly apply to inmates not on death row. In noncapital cases, an inmate has nothing to gain but everything to lose by delaying the filing of his federal claim: If his claim is denied, he serves the same length of time im prison whether the filing was delayed or not; on the other hand, if he succeeds in establishing his constitutional claim, the delay in filing would have brought him no benefit but a longer period of unnecessary imprisonment. Therefore, there is certainly no incentive for a non-death-row inmate to strategically delay a petition.

Contrary to the view that inmates intentionally withhold their claims, the BJS study suggested that delays in the filing of federal habeas corpus petitions are for the most part due to state postconviction proceedings. ${ }^{179} \mathrm{In}$ 1979 the average time from the date of conviction to the filing of a federal habeas corpus petition was a year and a half, but by 1995 that time had increased to over five years. ${ }^{180}$ This increase in the filing time is largely attributable to the prolonged state postconviction proceedings that prisoners must go through to satisfy the exhaustion doctrine, ${ }^{181}$ which has been viewed as "one of the most difficult procedural obstacles for state prisoners

176. H.R. CONF. REP. No. 104-518, at 111 (1996), reprinted in 1996 U.S.C.C.A.N. 924, 944.

177. See HANSON \& DALEY, supra note 167, at 17.

178. See, e.g., William French Smith, A Proposal for Habeas Corpus Reform, in Criminal JuSTICE REFORM: A BLUEPRINT 137, 145 (Patrick B. McGuigan \& Randall R. Rader eds., 1983); see also 141 CoNG. REc. S7803-01, at S7822 (daily ed. June 7, 1995) (statement of Sen. Nickles).

179. See HanSON \& DaLEY, supra note 167, at 29-30.

180. Id. at 29.

181. See id. at 29-30. For a discussion of the exhaustion doctrine, see supra Part 11.B.1. 
to overcome when seeking federal habeas corpus relief." 182 In essence, the exhaustion doctrine is responsible for the delays. ${ }^{183}$ Requiring a state inmate to first exhaust state postconviction remedies (with the constant risk of triggering the procedural-default doctrine) while imposing a one-year statute of limitations on the filing of his federal habeas corpus petition is like asking a person to run across a mine field at twice his normal speed, blindfolded.

Likewise, while repetitive petitions may become abusive, taking more than a year after conviction to file a first federal habeas corpus petition could hardly be categorized as such. On the contrary, those inmates barred by the one-year limitation may often be the ones who have most diligently prepared a meaningful petition. Filing a frivolous claim is easy, but a well reasoned, fact-based claim takes time, especially for inmates without benefit of counsel.

Anthony Burton's story challenges the policy presumption underlying the AEDPA's statute of limitations. He immediately sought advice from a California judge and, upon that advice, moved quickly to secure assistance of counsel to investigate new evidence of his innocence. When he finally learned of the California Supreme Court's denial of his state petition, at which time his attorney had ceased to represent him, he asked the prison guard for a book on federal habeas corpus practice and the relevant forms the very next day. Although the prison could not provide him with the requested book, he nonetheless filed his first and only federal habeas corpus petition in less than two months with the help of his wife. In a case like Burton's, the statute of limitations does not prevent abuse by foreclosing a prisoner's right to habeas corpus review; it prevents justice.

\section{IV}

\section{Actual Innocence as a Gateway Through the AEDPA's Statute OF LIMITATIONS}

The writ of habeas corpus "has been for centuries esteemed the best and only sufficient defence of personal freedom."184 An actual-innocence exception to the AEDPA's statute of limitations would enable the courts to continue to redress the most egregious injustice that can occur under our criminal justice system: the incarceration of an innocent person by an unconstitutional process. While it is impossible to assess how many people are in jail for crimes they did not commit, it is sobering to note that, since

182. Mello \& Duffy, supra note 30, at 490 (quoting Karen M. Allen et al., Federal Habeas Corpus and Its Reform: An Empirical Analysis, 13 RUTGERs L.J. 675, 690 (1982)).

183. Cf. Mark Tushnet \& Larry Yackle, Symbolic Statutes and Real Laws: The Pathologies of the Antiterrorism and Effective Death Penalty Act and the Prison Litigation Reform Act, 47 DuKE L.J. 1, 6 \& 29 (1997) (noting that courts must resolve the tension between the new filing deadline and the exhaustion doctrine because there is an obvious conflict of purpose).

184. Ex parte Yerger, 75 U.S. (8 Wall.) 85, 95 (1868). 
1973, 102 death row inmates have been released because of evidence of their innocence. ${ }^{185}$ Depriving an individual of life and liberty without just cause so violates the principles underlying American society that we would rather let a guilty man go free than incarcerate an innocent one. ${ }^{186}$ Absent a congressional revision of the statute, the federal courts should construe the AEDPA's statute of limitations in accordance with the purpose of the Great Writ to allow an actual-innocence exception to the AEDPA's statute of limitations. Further, courts should apply a probability standard, rather than a clear-and-convincing-evidence standard, in evaluating actual innocence claims so raised.

Part IV.A discusses the legal basis for an actual-innocence exception in the statute-of-limitations context and explams why the exception is necessary despite the tolling provisions in the AEDPA. Part IV.B examines how an actual-innocence exception to the statute of limitations may operate within the existing federal habeas corpus framework to achieve a balance among conflicting equitable concerns. Part IV.C argues that courts should employ the Schlup probability standard in adjudicating actual-innocence claims in the statute-of-limitations context.

\section{A. The Legal Basis and the Necessity for an Actual-Innocence Exception}

The AEDPA is silent on whether there should be an actual-innocence exception to the statute of limitations. It is clear, however, that the A.EDPA's statute of limitations is not absolute. The federal courts of appeals have consistently held that it is a procedural rather than a jurisdictional bar, and as such, is subject to equitable tolling in extraordinary circumstances. ${ }^{187}$ The question is, then, what constitutes an extraordinary circumstance? Under the cause-and-prejudice standard, ${ }^{188}$ few circumstances would constitute cause to justify a late filing. ${ }^{189}$ Under Supreme

185. Death Penalty Info. Ctr., InNocence: Freed from Death Row, at hitp://www.deathpenaltyinfo.org/Innocentlist.html (last visited Dec. 1, 2002). The average number of years between being sentenced to death and exoneration is eight years. Id. See also Daniel Givelber, Meaningless Acquittals, Meaningful Convictions: Do We Reliably Acquit the Innocent? 49 RUTGERs L. REv. 1317, 1318-20 \& nn.6-8 (1997) (providing a collection of news media reports on erroneous convictions of the innocent).

186. See In re Winship, 397 U.S. 358, 372 (1970) (Harlan, J., concurring) (noting that concern about the injustice that results from the conviction of an innocent person is reflected in the "fundamental value determination of our society that it is far worse to convict an innocent man than to let a guilty man go free").

187. See Dunlap v. United States, 250 F.3d 1001, 1004 \& n.1 (discussing and following other circuits' view that the one-year time bar is a procedural limitation rather than a jurisdictional bar).

188. See supra Part 1I.B.3.

189. See, e.g., Allen v. Lewis, 255 F.3d 798, 800 (9th Cir. 2001) (stating that "the prisoner must show that the 'extraordinary circumstances' were the but-for and proximate cause of his untimeliness"); Fisher v. Johnson, 174 F.3d 710, 714 (5th Cir. 1999) (finding that the fact that defendant did not receive notice of the statute of limitations until forty-three days after the AEDPA's effective date when a copy of the statute arrived in the prison library did not constitute an extraordinary circumstance); see also supra note 173 (attorney's error does not constitute extraordinary circunstances). But see Jorss v. 
Court precedent, actual innocence excuses the "cause" requirement in overcoming all the other postconviction procedural barriers. ${ }^{190}$ Logically, it should also excuse the cause requirement in overcoming the statute-oflimitations barrier.

Moreover, an actual-innocence exception to the statute of limitations is necessary despite the enumerated tolling provisions under the AEDPA. Subsection 2244(d)(1)(D) of the AEDPA recognizes that a prisoner should be able to challenge the constitutionality of his conviction on the basis of later-discovered evidence. It provides that in situations where new evidence is discovered after the date the judgment becomes final, the one-year statute of limitations shall run from "the date on which the factual predicate of the claim or claims presented could have been discovered through the exercise of due diligence." $" 191$ Some courts have construed this provision as an equitable tolling provision, ${ }^{192}$ and others have suggested that a sufficient showing of actual innocence may justify such an equitable tolling. ${ }^{193}$ However, unlike the provisions restricting second or successive petitions, there is no express actual-innocence exception to the statute-of-limitations provision. Because there can be no freestanding innocence claims, ${ }^{194}$ a textual interpretation of subsection (d)(1)(D) requires that the newly discovered evidence constitute factual predicate of a constitutional claim, not an innocence claim. ${ }^{195}$

Even if subsection (d)(1)(D) may be interpreted to allow tolling until the date on which the factual predicate supporting an innocence claim is discovered through the exercise of due diligence, it is still insufficient to cure the grave injustice done to those who were wrongfully convicted and who are innocent of the crime. First, what constitutes "factual predicate" of the claim remains unclear, and hence the start date for the statute of limitations remains undefined. In an application for writ of habeas corpus, notice pleading does not suffice. Federal habeas corpus rules require the petitioner to "specify all the grounds for relief which are available to the petitioner and of which he has or by the exercise of reasonable diligence should have knowledge and ... [to] set forth in summary form the facts supporting each

Gomez, 266 F.3d 955, 958 (9th Cir. 2001) (finding that the district court's erroneous dismissal of prior petition as unexhausted constituted an extraordinary circumstance beyond the petitioner's control); Valverde v. Stinson, 224 F.3d 129, 133 (2d Cir. 2000) (“[C]onfiscation of a prisoner's legal papers by a corrections officer shortly before the filing deadline may justify equitable tolling.").

190. See supra Part II.C.

191. 28 U.S.C. $\$ 2244(d)(1)(D)(2000)$.

192. See, e.g., Taliani v. Chrans, 189 F.3d 597, 598 (7th Cir. 1999).

193. See, e.g., Miller v. Marr, 141 F.3d 976, 978 (10th Cir. 1998).

194. See supra note 133 and accompanying text.

195. Technically, because the AEDPA expressly recognizes actual innocence claims as an exception to the bar on second and successive petitions, the statute of limitations for prisoners bringing their second or successive petitions on the basis of evidence of actual innocence may be tolled until the discovery of such exculpatory evidence. 
of the grounds thus specified."196 However, there is no clear guidance as to where to draw the line between hints and facts and as to whether the facts must be confirmed with reasonable effort. ${ }^{197}$ Without a clear standard, it is likely that when a prisoner spends a tremendous amount of time establishing the validity of the facts, a court may find that the initial piece of uncorroborated information would be deemed a "factual predicate" to start the statute-of-limitations period; if, however, a prisoner instead chooses to submit an application with the same piece of "raw" information, it may fail the fact-pleading requirement. This trap potentially eliminates any real chance a prisoner might have to successfully establish actual innocence within the time limit.

Second, the "due diligence" requirement is another trap for the unwary. As discussed in Part III.A, one year is hardly enough time for a confined pro se inmate to prepare a meaningful habeas corpus petition, ${ }^{198}$ particularly when the clain relies on newly emerged evidence. It is convenient to blame prisoners for inactivity, but prisoners generally lack the resources necessary to conduct a thorough investigation of the new evidence by themselves. If they hastily file a habeas corpus petition whenever soine new clue emerges, they will most likely be found to be abusing the system.

Third, evidence available at the trial but not discovered due to counsel's oversight or the defendant's poverty is not considered "new" evidence. For example, the emergence of DNA evidence has exonerated a considerable number of innocent prisoners. ${ }^{199}$ Yet a prisoner who could not afford DNA testing, or whose counsel simply neglected the possibility of DNA testing, at the time of the trial may not be able to present this strong evidence of innocence years later under the AEDPA's statute of limitations because that evidence would be deemed to have been available at the time of trial. This result is disturbing. If we accept that the petitioner is probably innocent of the crime, it should not matter how late that evidence of innocence is presented.

Professors Tushnet and Yackle were optimistic about courts' interpretation of the AEDPA's statute-of-limitations provision when they predicted that the AEDPA's provisions would only produce "marginal results"200

196. Habeas Corpus R. 2(c), supra note 67; see also 1 RANDY Hertz \& James S. Liebman, Federal Habeas Corpus Practice and Proceddure $\S 11.6$ (3d ed. 1998) (noting that the factpleading requirement "mandates that the petitioner at least summarily plead specific facts supporting each claim for relief").

197. If the facts require reasonable confirmation, a prisoner acting pro se would again lack the resources to file his claims.

198. See supra Part III.A.

199. See, e.g., Givelber, supra note 185, at 1319 n.7. See also DeAth Penalty INFo. CTR., supra note 185 (finding that in 12 out of 102 cases where death row inmates were released based on evidence of their innocence, DNA evidence was a substantial factor in establishing innocence).

200. Tushnet \& Yackle, supra note 183, at 47. 
because courts "are likely to reach a result rather more favorable to prisoners." ${ }^{201}$ This prediction did not turn out to be accurate. Although subsequent court decisions were consistent with almost all of their other predictions, ${ }^{202}$ the impact of the AEDPA's statute of limitations is nonetheless anything but marginal to those who are probably innocent but are denied the right of federal habeas corpus review. Tushnet and Yackle probably would not have foreseen the result in Anthony Burton's case. To avoid further injustice, courts should create an actual-innocence exception to the AEDPA's statute-of-limitations provision.

\section{B. Balancing Equitable Principles}

Convicted criminals are never popular. In the criminal justice context, it is easy for interests in comity, federalism, finality, and judicial resources to prevail over concerns about what is fair and just. As Professor Friedman observed, Justice O'Connor, "in her separate opinion in Withrow $v$. Williams, referred to the 'principles that inform our habeas jurisprudence' and then put them in this order: 'finality, federalism, [and] fairness.' Finality and federalism were discussed at length, while fairness received barely a mention." 203

However, actual innocence of one who is convicted by an unconstitutional process requires a rebalancing of the equitable principles. As the current Court has recognized, "concern about the injustice that results from the conviction of an innocent person has long been at the core of our criminal justice system." 204 Even if society can tolerate crooked prosecutors and incompetent lawyers in exchange for speedy justice as long as the system seemingly punishes the guilty, depriving the innocent of life and liberty would completely undermine the public's confidence in our criminal justice system. The remainder of this Section examines how an actual innocence exception to the statute of limitations may operate within the existing habeas corpus jurisprudence framework and keep conflicting equitable principles in balance.

The writ of habeas corpus affords the petitioner a federal review into the legality of his conviction, which by its nature calls for a careful scrutiny of the constitutionality of state laws and state courts' practice. There can be no meaningful review if the federal courts place deference to the states before their responsibility to the Constitution. As Justice Story once

201. Id. at 28 .

202. For example, Tushnet and Yackle predicted that courts would not apply the AEDPA's time bar retroactively and would include certiorari proceedings in the United States Supreme Court as part of "direct review" under $\$ 2244(\mathrm{~d})(1)(\mathrm{A})$. Id. at 28-29.

203. Friedman, supra note 39, at 491 (quoting Withrow v. Williams, 507 U.S. 680, 697-701 (1993) (O'Connor, J., concurring in part and dissenting in part)) (brackets original; internal citations omitted).

204. Schlup v. Delo, 513 U.S. 298, 325 (1995). 
noted: "The constitution has presumed ... that state attachments, state prejudices, state jealousies, and state interests, might sometimes obstruct, or control, or be supposed to obstruct or control, the regular administration of justice." ${ }^{205}$ Where there is a claim of innocence, the constitutionality of the state's process is most questionable and thus the state's determination of the related federal rights deserves little deference.

Advocates for comity and federalism may argue that the states should be trusted to adjudicate federal-rights claims. Data show that state convictions are in most circumstances respected by federal courts. According to the BJS study, during 1995 only $1 \%$ of federal habeas corpus petitions were granted and another $1 \%$ were remanded to state courts. ${ }^{206}$ These figures do not necessarily lead to the conclusion that state courts can be trusted to fairly adjudicate federal claims, however. For one thing, these figures may be the result of overdeference by the federal courts to the states given that most of the federal habeas corpus petitions are dismissed for failure to exhaust state remedies. ${ }^{207}$ For another, the very threat of federal review has perhaps motivated state courts to conduct their proceedings in a constitutional manner. At the very least, these low figures show that permitting federal habeas corpus review of time-barred petitions on the basis of actual innocence will not lead to any significant encroachment on states rights. ${ }^{208}$ The concern that federal courts, given the ability to hear actual-innocence claims, will trample on state courts by regularly overturning state convictions is overblown.

Fimality is another concern that is often raised. However, "since habeas corpus is by definition a reexamination of what went before, the writ works against finality." ${ }^{209}$ In Coleman v. Balkcom, then-Justice Rehnquist noted that delays in capital proceedimgs make it virtually impossible for states to enforce their criminal statutes and thereby lessen the deterrent effect of the punishment. ${ }^{210}$ For sonie, speedy justice may be the only way to ensure the legitimacy of state laws, achieve deterrence, and obtain public approval. However, one should not neglect the public fear and distrust that may arise as a result of incarcerating the innocent. Moreover, states' interest in finality is far greater in defending repetitive petitions than in defending delayed first petitions. Statutes and common-law doctrines prohibiting repetitive petitions are already in place; a statute of limitations is hardly necessary. Therefore, where states' interest in finality

205. Martin v. Hunter's Lessee, 14 U.S. (1 Wheat.) 304, 347 (1816).

206. HANSON \& DALEY, supra note 167, at 17.

207. See id.

208. Professor Friedman remarked that because so few people are granted the writ, it is "difficult to see what all the hullabaloo is about if this is the federalism concern." Friedman, supra note 39, at 536.

209. Weisselberg, supra note 17 , at $171 \&$ n.203.

210. 451 U.S. 949, 959 (1981) (Rehnquist, J., dissenting). 
is justified, allowing an actual-innocence exception to the statute of limitations will not undermine such interest.

Inevitably, a reexamination of the process will add to the courts' docket and potentially stress judicial resources. However, where the life or liberty of an innocent is at stake, even those gravely concerned about conservation of judicial resources have acknowledged that "the policy against incarcerating or executing an innocent man... should far outweigh the desired termination of litigation."211 Further, the notion that the dockets of federal district courts are inundated with frivolous habeas corpus petitions is greatly exaggerated. Granted, the filing of federal habeas corpus petitions over the years has increased tremendously. But such statistics should be examined in the context of the concurrent increase in the prison population and in the volume of civil litigation. ${ }^{212}$ As the table below shows, between 1980 and 2000, the number of inmates in state prisons increased by $299 \% .{ }^{213}$ However, the number of federal habeas corpus petitions filed per thousand state prisoners remained roughly the same over the twenty-year period. Moreover, during the twelve-month period ending March 31, 2001, a total of 254,523 civil cases were filed in federal district courts, only $8.2 \%$ of which were habeas corpus petitions filed by state prisoners. ${ }^{214}$

In addition to the small percentage of the habeas corpus petitions filed by state prisoners in federal district courts, "the one thing almost never suggested on collateral attack is that the prisoner was innocent of the crime. ${ }^{215}$ As such, allowing an actual-innocence exception to the statute of limitations would hardly burden the courts' dockets. To the contrary, without the time pressure, a petitioner having a meritorious actual-innocence claim is more likely to carefully develop his case rather than hastily file a petition and risk dismissal for lack of proof and be forever barred from raising the same claim under the successive-petitions doctrine. This careful preparation will in the end help to conserve judicial resources.

211. Friendly, supra note 90 , at 150 (intemal quotation omitted).

212. See Weisselberg, supra note 17, at 160-64.

213. The data in the table is compiled from the following: U.S. Dep't of Justice Bureau of Justice Statistics, Prisoner Petitions Filed in U.S. District Courts, 2000, with Trends 1980-2000 (Dec. 2001), at http://www.ojp.usdoj.gov/bjs/abstract/ppfusd00.htm; U.S. Dep't of Justice Bureau of Justice Statistics, Prison and Jail Inmates at Midyear 2000 (Mar. 2001), at http:/www.ojp.usdoj.gov/bjs/abstract/ pjim00.htm; U.S. Dep't of Justice Bureau of Justice Statistics, Prisoners in 1994 (Aug. I995), at http://www.ojp.usdoj.gov/bjs/abstract/pi94.htm.

214. Administrative Office of the U.S. Courts, Federal Judicial Caseload Statistic, TABLE C-3 (Mar. 31, 2001), at http://www.uscourts.gov/caseload2001/contents.html. This does not include petitions from state death-row inmates, which constituted $.08 \%$ of the total civil cases commenced. Id.

215. Friendly, supra note 90 , at 145. 
Federal Habeas Corpus Petitions

Filed by State Prisoners, 1980-2000

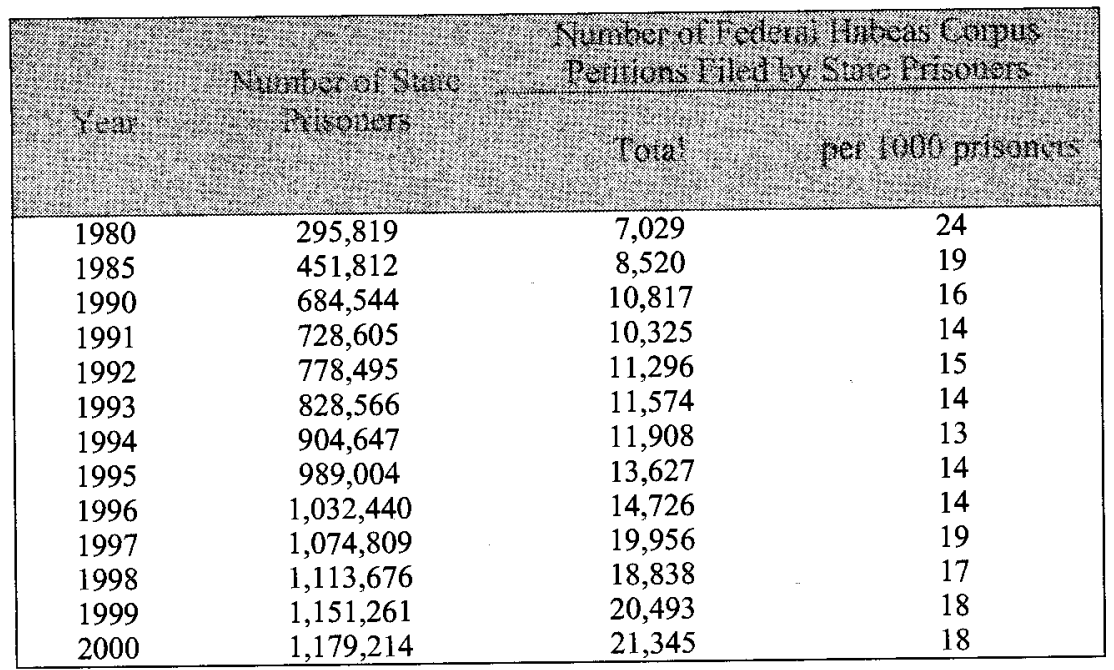

Allowing an actual-innocence exception to the time bar will maintain the fragile balance among conflicting interests. A limited exception based on innocence is consistent with the Court's general emphasis on comity and finality, the equitable principles from which the actual-innocence doctrine sprung. At the same time, the safety-valve function of an actualinnocence exception would be welcomed by those who are concerned by the grave impact of the statute of limitations on individual liberty, fundamental fairness, and the integrity of the justice system.

\section{The Case for Applying the Schlup v. Delo Probability Standard}

Courts should use the probability standard articulated in Schlup v. Delo, ${ }^{216}$ rather than a clear-and-convincing-evidence standard, in evaluating the validity of actual-innocence claims in the statute-of-limitations context. First, the statute does not expressly prohibit the application of a probability standard in this context. Although the AEDPA explicitly prescribes a clear-and-convincing-evidence standard to actual-innocence claims in the context of second or successive petitions, neither the text nor the legislative history indicates that the same standard should apply in the statute-of-limitations context. ${ }^{217}$

Second, this silence creates a gap that courts can and should fill according to habeas corpus principles established by the Supreme Court. The Court has historically taken the lead in developing habeas corpus

216. 513 U.S. 298 (1995).

217. As has been noted, the AEDPA is silent on whether there should be an actual-innocence exception to the statute of limitations. 
jurisprudence. As noted above, the Court has already employed a probability standard to evaluate actual-innocence claims. Therefore, federal courts can apply a probability standard to actual-innocence claims in the statuteof-limitations context without either conflicting with the AEDPA or departing from the Court's precedents.

Some may argue that the Court's reasoning should not be applied when Congress chose to ignore Schlup. It is true that, in the context of second and successive petitions, Congress was aware of the AEDPA's departure from the Schlup standard and concluded that only a clear-andconvincing-evidence standard in examining actual-innocence clains would serve the purpose of finality. ${ }^{218}$ Senator Hatch attacked the Schlup Court's decision as "exacerbat[ing] the confusion in the lower courts [and] undermin[ing] the finality of lawful convictions. ${ }^{.219}$ However, if we accept that concerns for finality must yield to concerns for fundamental justice where a probably innocent person might have been convicted through an unconstitutional process, Senator Hatch's reasoning must fail. Moreover, given the small percentage of state prisoners who actually file for federal habeas corpus review and given the grave consequences of a restrictive statute of limitations, it cannot be said that the state's interest in finality is so great that courts should ignore a probable showing of innocence in cases of time-barred petitions and incarcerate or execute the innocent just so the state can achieve finality. ${ }^{220}$ This result would violate the most basic concept of what is just and fair and dramatically undermine the public's confidence in our criminal justice system.

Third, a probable showing of actual innocence is only a gateway through which the petitioner must pass to bring his time-barred constitutional claims. At the stage of assessing the validity of an actual-innocence claim, an erroneous finding by the court against the petitioner would foreclose his chance of regaining liberty; by contrast, if the court made an erroneous finding in favor of the petitioner, the state would still have a chance to defend the constitutionality of its process. Senator Hatch argued that a probability standard of proof would simply open another loophole because "liberal judges who are opposed to the death penalty do not want the death penalty imposed, [and] there will be an incentive for them to find that there is probable innocence under [a probability standard]."221 However, by the same argument, judges who disfavor federal intervention in state decisions would have an incentive to find that there is no innocence under the clear-and-convincing-evidence standard regardless of the strength of the

218. See supra note 155 .

219. 141 CoNG. REC. S7803-1, at S7825 (daily ed. June 7, 1995) (statement of Sen. Hatch).

220. For an analysis of applying Schlup's probability standard to successive petitions, see generally Oh, supra note 92.

221. 141 CoNG. REC. S7803-1, at S7825 (daily ed. June 7, 1995) (statement of Sen. Hatch). 
evidence. The latter result would be far more disturbing because the "fundamental value determination of our society" is that "it is far worse to convict an innocent man than to let a guilty man go free." 222

\section{CONCLUSION}

It is perhaps easy to forget that in the context of a habeas corpus petition, "[t]he proponent before the Court is not the petitioner but the Constitution of the United States." 223 Under current habeas corpus doctrines, the purpose of the Great Writ is being thwarted by the procedural obstacles. The exhaustion doctrine, the procedural-default rule, and the second- and successive- petition doctrines all value comity, federalism, finality, and judicial resources more than an individual's right to be free from unjust imprisonment. The AEDPA's one-year statute of limitations has imposed an additional and unprecedented procedural barrier that blocks even innocent, first-time petitioners from seeking relief.

The actual-innocence doctrine has historically played a vital role in achieving a delicate balance between conflicting equitable principles. Allowing the petitioner to overcome the one-year time bar by a showing of actual innocence adjudged under the Schlup probability standard may redress some of the AEDPA's harsh impact. The doctrine acts as a safety valve, perhaps the last safety valve, to guard against unconstitutional intrusions on personal liberty. It ensures that the interests in protecting the life and liberty of the innocent prevail over concerns about comity, federalism, finality, and judicial resources. 
